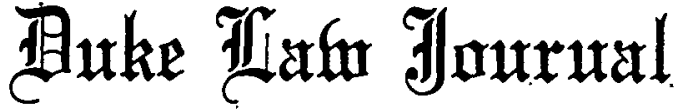

\begin{tabular}{lll}
\hline VOLUME 1982 & FEBRUARY & NUMBer 1 \\
\hline
\end{tabular}

\section{THE NEWS-GATHERING/PUBLICATION DICHOTOMY AND GOVERNMENT EXPRESSION}

\author{
STEVEN Helle*
}

The central issue throughout the history of the struggle for the freedom of the press has been the appropriate accommodation of government authority with press rights. ${ }^{1}$ The struggle has produced no

- Assistant Professor, University of Illinois. B.S. 1976, M.A., J.D. 1979, University of Iowa. Copyright, Steven Helle 1982.

With thanks to Randy, whose ideas will always be reflected in my own.

1. See F. Siebert, Freedom of the Press IN ENGland, 1476-1776 (1952):

One basic assumption appears to be common to all theories of liberty of the press

.... This assumption is that freedom of the press is not and never can be absolute. All agree that some forms of restraint are necessary and that the government has a legitimate function to define the limitations. They differ only as to the nature and number of these limitations.

Id. 9. As Professor John Hallowell noted with regard to liberalist theory, the "central problem . . . is the relation between the individual and authority." J. HALLOWELL, MaIN CURRENTS IN MOdern Political Thought 89 (1950). But of. L. Tribe, American Constitutional Law at v (1978) ("conventional ways even of stating the choices between greater freedom or equality, on the one hand, and greater governmental power, on the other hand . . . are remarkably unilluminating as well as misleadingly ahistorical") (emphasis in original).

The question whether freedom of the press differs froin freedoin of speech under the first amendment to the Urited States Constitution lias been debated intensely in recent years. See First Nat'1 Bank v. Bellotti, 435 U.S. 765, 797-802 (1978) (Burger, C.J., concurring); Herbert v. Lando, 568 F.2d 974, 986-91 (2d Cir. 1977) (Oakes, J., concurring), rev'd, 441 U.S. 153 (1979); 568 F.2d at 997 (Meskill, J., dissenting); Abrams, The Press Is Different: Reflections on Justice Stewart and the Autonomous Press, 7 Horstra L. Rev. 563 (1979); Baker, Press Rights and Government Power to Structure the Press, 34 U. MiamI L. Rev. 819, 828-36 (1980); Bezanson, The New Free Press Guarantee, 63 VA. L. REv. 731, 731-32 (1977); Blanchard, The Institutional Press and Its First Amendment Privileges, 1978 Sur. CT. REv. 225, 227; Lange, The Speech and Press Clauses, 23 U.C.L.A. L. Rev. 77, 118-19 (1975); Lewis, A Preferred Position for Joumalism?, 7 HoFSTRA L. Rev. 595 (1979); Nimmer, Introduction-Is Freedom of the Press a Redundancy: What Does It Add to Freedom of Speech?, 26 HAstinos L.J. 639, 650, 658 (1975); Oakes, Proof of Actual Malice in Defamation Actions: An Unsolved Dilemma, 7 HoFsTRA L. REv. 655, $674-78$ (1979); Sack, Reflections on the Wrong Question: Special Constitutional Privilege for the Institutional Press, 7 HoFsTRA L. Rev: 629 (1979); Stewart, “Or of the Press," 26 HAstings L.J. 631, 633-34 (1975); Van Alstyne, 
clear winner. Equipoise between press and government has been suggested as the ideal implicit in our constitutional scheme. ${ }^{2}$ But the more popular view may be that "[t]he Constitution . . . establishes the contest, not its resolution."3

Searching the Constitution for guidance, various players have extrapolated sets of principles that favor one side or the other. The historic libertarian theory and the relatively recent social-responsibility theory encompass these competimg principles. Depending on whether the courts have found a libertarian or a social-responsibility theory of press freedom apposite, the victory has gone either to the press or to the government. ${ }^{4}$ The choice of controlling theory is therefore of utmost importance in the developing field of news-gathering law. For when access is sought to premises or records under government control, the theory selected is crucial in determining whether press or government will benefit from a presumption of right.

Today the presumption appears to favor government discretion im deciding to close its doors to conceal its records. 5 When asserting a news-gathering right, press and public inevitably assume the posture of

Comment-The Hazards to the Press of Claiming a "Preferred Position," 28 HAstings L.J. 761, 768-70 (1977); Note, Examining the Institutional Interpretation of the Press Clause, 58 TEx. L. REv. 171 (1979); Comment, Problems in Defining the Institutional Status of the Press, 11 U. RICH. L. REV. 177, 205-07 (1976).

For other commentary that has touched on this issue, see sources cited in Lange, supra, at $77 \mathrm{n} .4$; Sack, supra, at $633 \mathrm{n} .27$. The first salvo in this debate may have been fired many years ago, however, when President Franklin Roosevelt termed the press clause of the first amendment "pure surplusage." See M. Blanchard, The Hutchins Commission, The Press and the ResponsiBILITY CONCEPT 6 (Association for Education in Journahism Monograph No. 49, 1977). See also id. 252-80 (survey of early cases dealing with asserted institutional status or privilege for press).

It is assumed in this article that the media-whose business it is to compile and disseminate information-is most likely to avail itself of access to government information. Much of the analysis, however, applies equally to the public. Indeed, the "press privilege" debate may divert attention from the inore basic issues addressed lerein.

Bezanson's focus on independence from government and his analysis of private rather than public interest is largely consistent with the propositions advanced here, except that he interprets those principles only in relation to the press clause of the first aunendment. See Bezanson, supra, at 732, 748-49, 751. It is not important for present purposes whether the courts ultimately embrace Bezanson's interpretation or that of other commentators regarding the suggested dichotomy between the speech and press clauses, as long as the courts maintain traditional first amendment emphasis on the above principles in this type of case.

2. See A. Bickel, The Morality of Consent 86-88 (1975). See also F. Watkins, The Polttical Tradition of the West-A Study in the Development of Modern Liberalism 267-68 (1948).

3. Stewart, "Or of the Press," 26 HASTings L.J. 631, 636 (1975).

4. Compare notes 21-52, 76-98 infra and accoinpanying text with notes 123-54, 177-210 infra and accompanying text.

5. See notes 223-300 infra and accompanying text. 
disapproving of the government's choice to cloak itself from scrutiny. ${ }^{6}$ Thus, it seems incumbent on press and public not only to object, ${ }^{7}$ but also to bear the burden of demonstrating the desirability of access or the unconstitutionality of the status quo. ${ }^{8}$ The establishment of the contours of a news-gathering right one step at a time has reinforced the legitimacy of government secrecy at every step. ${ }^{9}$ The proposition that government in a given case should open its doors rejects the presumption that government should not have closed its doors in the first place.

The Supreme Court has bifurcated the press's function into gathering and publication, giving greater protection-under prior-restraint analysis-to publication. ${ }^{10}$ By according news-gathering less protection the Court has given implicit sanction to the presumption that it is the right of the government to deny information to its citizens. As it has emerged, this presumption has become almost irrebuttable. If the Court's distinction between gathering and publication is correct, the former may be of greater practical significance and broader constitutional import than the latter. If the dichotomy is specious, as this article contends, then one's choice of theory to define the duties of government and press generally decides the contest.

The first step is to define the choices; therefore, this article initially analyzes the disparate rights and duties of the press under the libertarian and social-responsibility theories. Next, the birth and potential growth of the news-gathering right are examined. Finally, a resolution of the contest is proposed in which the focus shifts from a news-gathering right by the press on behalf of the public to a general obligation of government to provide unrestricted access to information. This change in analytic orientation eschews a surrogate function for the press on behalf of the "public's right to know."11 This special status of the press

6. See Richmond Newspapers, Inc. v. Virginia, 448 U.S. 555 (1980); Houchins v. KQED, Inc., 438 U.S. 1 (1978); Saxbe v. Washington Post Co., 417 U.S. 843 (1974); Pell v. Procunier, 417 U.S. 817 (1974).

7. See Gannett Co. v. DePasquale, 443 U.S. 368, 375-76, 392 (1979); id. at 400-01 (Powell, J., concurring).

8. See id. at 400-01 (Powell, J., concurring). Enactment of open-meetings laws, for example, arguably establishes instances in which the public need not shoulder this burden. See WSDR, Inc. v. Ogle County, No. 80-MR-27, shp. op. at 1 (15th Judicial Cir. Ct., Ogle County, Ill. March 17, 1981), affd, 100 Ill. App. 3d 1008, 427 N.E.2d 603 (1981).

9. To paraphrase Professor Bickel, to take the negative is to render the debate legitimate by engaging in it. See A. Bickel, The Morality of Consent 73 (1975). See also Pember, The Burgeoning Scope of "Access Privacy" and the Portent for a Free Press, 64 Iowa L. Rev. I155, 1189 (1979): "The mere existence of [freedom of information] laws seemingly concedes governmental power to regulate press access. . . Additionally, if Congress has the power to grant access, it has the power to revoke such a grant."

10. See notes 224-26, 261-67, 292 infra and text accompanying notes 224-26, 261-67 infra.

11. See note 160 infra and accompanying text. 
should not determine the government's duty to disclose; ${ }^{12}$ rather the affirmative responsibility of the government to keep its operations open to inspection or to justify its secrecy should be the sole determinant. ${ }^{13}$ It is suggested that the Supreme Court's analysis of a news-gathering right is a departure from traditional first amendment doctrine ${ }^{14}$ and should be abandoned in favor of a presumption that the government has no right not to speak; government should be presumed to have a duty to commumicate information within its possession. Under this analysis, the private interests of the press are maintained in accordance with libertarian theory, and the government assumes the duty of acting in the public interest in accordance with social-responsibility theory.

\section{LIBERTARIAN AND SOCIAL-RESPONSIBILITY THEORIES}

Two theories have laid claim to constitutional justification under the first amendment. One's choice between them dictates the role of the press and agreement or disagreement with the Supreme Court's news-gathering analysis. Confidence in government's proficiency and self-discipline, and the role of the press vis-a-vis the public distinguish the two theories.

A. Libertarian Theory of the Press.

The writings of John Milton ${ }^{15}$ and John Locke16 generally are credited with containing the roots of the libertarian theory, ${ }^{17}$ although Greco-Roman and early Christian thinkers contributed to libertarian

12. For a more thorough explanation of the potential for governmental imposition of affirmative obligations when the press acts on behalf of the public's right to know, see notes 155-76, 28489 infra and accompanying text.

13. At the very least, concern with issues such as whether the press's news-gathering right is greater than that of the public, see note 1 supra, and notes 234-44 infra and accompanying text, has obscured the issue of the extent to which government should be accountable. See Houchins v. KQED, Inc., 438 U.S. 1, $25-38$ (1978) (Stevens, J., dissenting).

14. See notes 245-55 infra and accompanying text.

15. See J. Milton, Areopagrtica (Eng. Rep. 1972) (1st ed. n.p. 1644).

16. See J. LOCKE, A Letter Concerning Toleration, reprinted in 6 THE WORKS OF JOHN LOCKE 1 (London 1823) (1st ed. n.p. 1689); J. LOCKe, OF HUMAN UNDERSTANDING, reprinted in 1-3 THe WORKS OF JOHN LOCKe (London 1823) (1st ed. n.p. 1689); J. LOCKe, SECOND TREATISE OF CIVIL GOVERNMENT, reprinted in 5 THE WORKS OF JOHN LOCKE 338 (London 1823) (1st ed. n.p. 1689).

17. See M. Frankin, The First amendment and the Fourth Estate 10-12 (1977); W. RIvers, W. Schramm \& C. Christians, Responsibility in Mass Communication 40 (3d ed. 1980).

Professor Jay Jensen has identified numerous variations of "liberalism." J. JENSEN, LIBERALISM, DeMOCRACY AND THE MASS MEdAA 15-16 \& n.16, 28 (Institute of Communications Research, University of Illinois at Urbana-Champaign, Monograph 1959). For example, classical liberalism - the body of thought traditionally associated with seventeenth and eighteenth century thinkers - has been viewed as a socio-economic, religious, and pohitico-legalistic movement. See id. 17-26; J. Hallowell, supra note 1, at 89-92, 115-17, 119-24, 129-30, 135-40. 
fundamentals. ${ }^{18}$ Libertarians espouse diversity of expression through a free and open exchange of ideas as the best means of achieving truth. ${ }^{19}$ In addition to promoting the discovery of truth, uninhibited expression fosters attainment of self-fulfillment and control of governmental abuse. ${ }^{20}$ Realization of these values depends on adherence to the following operative principles: independenee from government and emphasis on the right of the individual-the speaker-as opposed to the right of the public.

1. Independence from government. The "self-righting process" envisioned by John Milton illustrates the libertarians' belief in natural forces that skew if government violates the principle of individual independence. In his 1644 treatise on intellectual freedoin, Areopagitica, Milton advocates the derivation of truth from the free expression of all opinions, unrestrained by government endorsement or suppression of any position. ${ }^{21}$ John Stuart Mill elaborates on this theme and criticizes

18. J. JeNSEN, supra note 17 , at 31-43:

Among the fundamental Liberal ideas inherited from the Greeks was the notion of rational, moral men living in a universe ruled by transcendental rational and moral law. ...

... And Stoic humanitarianism and the Christian theory of the person, softening the harsh materialism of the Greek atomists, carried into the main strean of Liberal thought an egalitarianism which not only imdelibly marked the character of Classical Liberalism, but was crucial also to the development of Modern Democracy.

Id. 31; see J. HALLOWELL, supra note 1, at 111; F. WATKns, supra note 2, at x-xi, 3-61.

19. See J.S. MIIL, ON LIBERTY 21, 55-56 (C.V. Shields ed. 1956) (1st ed. n.p. 1859); J. Milton, AREopagitica 74-76 (Eng. Rep. 1972) (1st ed. n.p. 1644). Free and open expression also facilitates decisionmaking and provides a means by which conflicts can be resolved without resort to physical force. T. EMERSON, The System of FreEDOM OF EXPRession 7 (1970). The concept of free, uninhibited expression was later popularized through the metaphor of the "marketplace of ideas." See Abrams v. United States, 250 U.S. 616, 630 (1919) (Holmes, J., joimed by Brandeis, J., dissenting). See also Dennis v. United States, 341 U.S. 494, 584 (1951) (Douglas, J., dissenting) (falsehood is exposed when ideas compete in the market); Umited States v. Associated Press, 52 F. Supp. 362, 372 (S.D.N.Y. 1943), affd, 326 U.S. 1 (1945) (first amendment presupposes "multitude of tongues").

Diversity of expression is not unique to libertarian theory. Social responsibility theorists also cndorse the value of such diversity, but they contend that libertarian principles in fact have not yielded diversity. See J. BARRon, FReEdom of THE PRESS FOR WHOM? $82-83$ (1973); Barron, Access to the Press-A New First Amendment Right, 80 HARv. L. Rev. 1641, 1643-47 (1967). But see Bezanson, Herbert v. Lando, Editorial Judgment, and Freedom of the Press: An Essay, $1978 \mathrm{U}$. ILL. L. F. 605, 611-22 (marketplace does operate in mass-media setting, albeit roughly, but in any event its operation is not the sole jnstification for freedom of the press).

20. See generally T. EMERson, supra note 19, at 6-7; Blasi, The Checking Value in First Amendment Theory, 1977 AM. B. Found. RESEARCH J. 521, 529-54; Cass, First Amendment Access to Government Facilities, 65 VA. L. REv. 1287, 1310-12 (1979); Karst, Equality as a Central Principle in the First Amendment, 43 U. CHI. L. REv. 20, 23-26 (1975).

21. See J. Milton, Areopagitica (Eng. Rep. 1972) (1st ed. n.p. 1644):

And though all the windes of doctrin were let loose to play upon the earth, so Truth be in the field, we do injuriously by licencing and prohibiting to misdoubt ler strength. Let her and Falshood grapple; who ever knew Truth put to the wors, in a free and open 
those who would attempt to cull the falsehoods from this exchange. Not only does Mill agree with Milton that government is unable to ascertain "truth,"22 but he identifies the value to mankind of even the expression of definitive falsehood: "If the opinion is right, [mankind is] deprivcd of the opportunity of exchanging error for truth; if wrong, they lose, what is almost as great a benefit, the clearer perception and livelier impression of truth, produced by its collision with error."23 Thus, government intervention in the process of free expression "rob[s] the human race." 24

Although not specifically writing about liberahsm, Professor Vimcent Blasi's characterization of pubhic officials as a citizen's potential oppressors rather than his agents ${ }^{25}$ is consonant with liberalist philosophy. Government is the "chief foe of liberty,"26 and any governmental breach of neutrality toward expression is gravely suspect. ${ }^{27}$ American colomists ${ }^{28}$ expressed great concern about the penchant of government to pursue aggressive expansion of its authority. ${ }^{29}$ Alexander Hamilton

encounter? ... [I] is not possible for man to sever the wheat from the tares, the good fish from the other frie; that must be the Angels Ministery at the end of mortall things. Yet if all cannot be of one mind, as who looks they should be? this doubtles is more wholsome, more prudent, and more Christian: that many be tolerated rather than all compell'd.

Id. 74-76.

Jefferson's landshide re-election in 1804 proved to him the efficacy of the self-righting process.

See Second Inaugural Address (Mar. 4, 1805), reprinted in 3 THE WRITINGS OF THOMAS JEFFERSON 381-82 (Definitive ed., A. Bergh ed. 1905).

22. J.S. MILL, supra note 19, at 21-22.

23. Id. 21; see id. 55-56, 64. See also W. Hocking, Freedom of the Press 95 (1947):

A socially authoritative control of the allowable contents of the public idea pool might save the mind from confusion, but at the cost of also saving it from the arduous effort to reach valid judgments; it would tend to deprive society of a citizenship prepared to fend off illusions and shams through its experience of their nature.

For a persuasive and well-reasoned view that even repetition of others' falsehoods serves first amendment values and should be protected, see Note, Protecting the Public Debate: A Proposed Constitutional Privilege of Accurate Republication, 58 TEx. L. REv. 623, 630-31 (1980).

24. J.S. MiLL, supra note 19, at 21.

25. Blasi, supra note 20 , at 564.

26. Peterson, The Social Responsibility Theory of the Press, in F. Siebert, T. Peterson \& W. SChramm, Four Theories of the Press 76 (1956).

27. See Bezanson, supra note 1, at 734.

28. Professor Blasi "casts some doubt" on the arguments made by Dean Leonard Levy, see L. LeVY, Freedom of SPEech AND Press: Legacy of SuPPression IN EARLy AMERICAN HisTORY 246-49 (1963), that a hbertarian view of the first amendment did not prevail until after the debate surrounding the Alien and Sedition Acts of 1798, Blasi, supra note 20, at $536 \mathrm{n} .60$. See also Z. Chafee, JR., Free Speech in the UNited States 22 (1941). For an entertaiming criticism of those who attempt to divine the framers' intent, see Note, Good Intentions, New Inventions, and Article $V$ Constitutional Conventions, 58 TEX. L. REv. 131 (1979).

29. See B. Bailyn, The Ideological ORIgins of the AMERICAN Revolution 56 (1967); Bezanson, supra note 1, at 783; Lewis, Keynote Address: The Right to Scrutinize Government: Toward a First Amendment Theory of Accountability, 34 U. MIAMI L. REV. 793, 805-06 (1980). See generally J. LOCKE, SECOND TREATISE OF CIVIL GoveRnMENT, supra note 16, at $\$ 1$, at 338 ; 
proposed that in a government of enuunerated powers the absence of specific authority to restrain expression suffices to preserve liberty of the press.30 Thomas Jefferson thouglit that press independence requires explicit protection; he wrote that "free presses" are a "fence agamst wrong" and that the states "had ... delineated ... these fences . . . in . . . declarations of rights and constitutions."31 Government interference with speech is particularly alarming to a libertarian, not only because it represents an incursion on individualism and a skewing of the self-righting process, but also because such interference undermines the ability of speakers to clieck governmental excess.32 This "checking value" of expression lias even been posited as "the primary function of the press under the libertarian view." 33

Professor Blasi suggests that free expression, as a force against abuse of official power, was perhaps the foremost concern among the drafters of the first amendment. ${ }^{34}$ In his excellent treatise on the checking function, Blasi reasons that the abuse of official power, which is likely to occur, ${ }^{35}$ is a more serious concern than the abuse of private power. ${ }^{36}$ Blasi asserts the need for professional critics of government who are able to reacli mass audiences to effect opposition to a particular official or policy. ${ }^{37}$ Blasi postulates that this system presupposes popular sovereignty, ${ }^{38}$ perhaps the essential element of a liberalist phi-

$\S 137$, at $420-21 ; \S 143$, at $424 ; \S 229$, at 474 . The drafters of the American Declaration of Independence and the U.S. Constitution borrowed heavily from Locke. W. KENDALL, JOHN LOCKE AND THE Doctrine of Majority RUle 58 (llinois Studies in the Social Sciences, Monograph No. 2, 1941).

30. The Federalist No. 84 (A. Hamilton). Other Federalists had similar perspectives. See E. Hudon, Freedom of Speech and Press in America 1-4 (1963).

31. Letter from Thomas Jefferson to Noah Webster (Dec. 4, 1790), reprinted in FREEDOM OF the Press from Zenger to Jefferson: Early American Libertarian Theories 342 (L. Levy ed. 1966); see 11 The Writings of Thomas JefFerson 33-34 (Definitive ed. A. Bergh ed. 1907) (letter to Judge John Tyler of June 28, 1804) (freedom of the press as a "most effectual" avenue to truth should not be manacled and will in turn place "manacles" on those who would take advantage of governmental office).

32. "No government ought to be without censors; and where the press is free, no one ever will." Letter from Thomas Jefferson to President George Washington (Sept. 9, 1792), reprinted in 8 The Writings of Thomas Jefrerson 406 (Definitive ed., A. Bergh ed. 1907).

33. Bezanson, supra note 1, at 735; see Siebert, The Libertarian Theory of the Press, in F. Siebert, T. Peterson \& W. Schrami, Four Theories of the Press 47, 51 (1956).

34. See Blasi, supra note 20 , at $527-28,533$.

35. Id. at $529 \&$ n.24, 541. It certainly cannot be doubted that the public sector invariably attempts to expand its influence over the private sector. See, e.g., Moynihan, State vs. Academe, HARPER's, Dec. 1980, at 31.

36. Blasi, supra note 20 , at $538-39$.

37. Id. $541-42$.

38. Id. 542. "For if one does not approve a significant role for the ordinary citizen as the ultimate judge of official conduct, there is little reason to place as much emphasis on mass communication as does a proponent of the checking value." Id. 
losophy. This concept contemplates that the government is a mere trustee of the authority ultimately vested in the electorate.$^{39}$ If the citizenry is to exercise its veto power effectively in those instances in which public officials abuse their trust, ${ }^{40}$ then a premium must be placed on the ability of professional critics to disseminate information about the behavior of the officials.41 And as Blasi notes, "A proponent of the checking value ... places particular emphasis on the acquisition of information." 42 But whether a given practice fosters the flow of inforination to recipients is not the determinative consideration..$^{43}$ Rather, journalistic autonoiny from government is the apparent keystone to the checking function. As "perhaps the most important imphication of the checking value," 44 journalistic autonomy enables the professional critic to "develop an internal ethos that emphasizes such qualities as independence, vigor, innovativeness, and public responsibility." 45 It does not necessarily follow that journalists are nore objective if they have the benefit of autonoiny; ${ }^{46}$ indeed, they may be ardently partisan in

39. See Chisholm v. Georgia, 2 U.S. (2 Dall.) 419, 457 (1793) (opinion of Wilson, J.); J. LOCKE, SECOND TREATISE OF CIVIL GOVERNMENT, supra note 16, \& 1, at 338; \& 149, at 426-27; \$§ 221-222, at 469-71; \$\$ 240-243, at 483-85; The FEDERAList No. 49, at 339 (J. Madison) (J. Cook ed. 1961); Letter from James Madison to Thomas Jefferson (Oct. 17, 1788), reprinted in 5 The WRITINGS OF JAMES MADison 272-73 (G. Hunt ed. 1904); Siebert, supra note 33, at 43.

40. Blasi did not envision a system by which it was necessary for the citizen to contribute on a continuing basis to the formation of public policy. Blasi, supra note 20, at 542, 561-62; see D. Gillmor \& J. BarRon, Mass Communications Law 17 (3d ed. 1979).

41. Blasi, supra note 20 , at 609 .

42. Id. 603. Blasi made the remark in the context of advocating that the checking value strengthens reporters' claims to a testimonial privilege. Id. For elaboration on the potential benefits of the checking value and its implications, see id. 589 (elimination of vicarious liability for defamation may promote publication of unconventional ideas which are encouraged by proponents of checking value); id. 603 (claim of testimonial privilege for reporters strengthencd by checking value which emphasizes acquisition of information); id. 628-29 (right of introduction-in addition to right to reply-may permit "critics of government to break through the mist of 'newspeak' that tends to dull almost everyone's response to public events" and to promote the introduction of new subjects of discussion). See generally id. 631-32.

43. Professor Lillian BeVier advances a provocative argument that promoting the flow of information should not be a significant consideration because the "right to know" finds no support in constitutional principles. BeVier, An Informed Public, an Informing Press: The Search for a Constituitional Principle, 68 CALIF. L. REv. 482, 500-10 (1980); see Dworkin, Is the Press Losing the First Amcndment?, ThE NEW YORK ReVIEW OF BOOKS 49, $51-52$ (Dec. 4, 1980).

44. Blasi, supra note 20, at 623. Elsewhere Blasi thought journalistic autonomy likely was a "prime consideration" for most proponents of the checking value. Id. 590.

45. Id. 587.

46. The journalistic ethic of objectivity, as commonly understood, may be a disservice to the reader who cannot read between the limes or assimilate sufficient material froin other sources to assess accurately the practical merit of a given position. It may not be enough for the press to report only both sides of an issue because the press then fails to "evaluate for the reader the trustworthiness of conflicting sources, [or to supply] the perspective essential to a complete understanding of a given situation." Peterson, supra note 26, at 88 . To report events impartially, with- 
attacking what they perceive as governmental abuse. 47

Independence from government has a symbolic value ${ }^{48}$ that may help to engender in the press a self-image as a participant in the system of checks and balances. 49 By opining that nonregulation "should generate reportorial priorities that are determined nore by a sense of pubhic responsibility than by a fetish for profit inaximization,"50 Blasi clearly opposes social-responsibility theorists who envision "a benevolent government" establishing the ground rules ${ }^{51}$ to ensure dissemination of all appropriate facts and opinions.

The libertarian principle of independence may derive from several first amendment values, but its roots seem nost firmly entrenched in the checking value. For no other value is independence so essential. Perhaps, as social-rcsponsibility proponents may argue, government intervention facilitates the realization of diversity of expression. ${ }^{52}$ But it seems a fortiori impossible to conteinplate any significant role for government if the focus is on the value of checking government.

2. Preeminence of private interests. Likewise fundamental to libertarian theory is an emphasis on private rather than public interests. The principle of the preeininence of private interests both shares and

out interpreting their significance or placing them in a context, may result in an "objective," yet distorted picture. See T. CROUSE, THE BOYS ON THE Bus 269-70, 323, 387-38, 392 (1972).

Arguably, objective truth-even if attainable-is distinguishable from news. W. LIPPMAN, Public OpINION 226 (1965). Reporters inay not see themselves reporting. "truth," but rather focusing attention on aspects of a situation that an audience can nost readily comprehend. See id. 221-22. Such a focus necessarily yields a misrepresentation in the eyes of those who would have interpreted the significance of the event differently. See $i d$. Thus understood, the ethic of objectivity is violated not when the reporter einphasizes, simplifies, or appeals to stereotypes, but when he deliberately fabricates without foundation in fact. The former may further the checking value, but the latter furthers only the purpose of the reporter.

47. To give equal attention to the view being criticized by itself lends credibility to the contrary position. See A. BICKEL, THE MORALITY OF CONSENT 73 (1975). As Blasi notes,

[f]or the process of checking official misconduct sometimes requires the press to behave

as a vigorous, unabashed partisan .... There may be, after all, occasions when the attention of readers could be diverted by boring, confusing, or brilliantly demogogic responses of officials who are being criticized by the press. Also, in a particular campaign to expose official abuse, the morale of reporters and editors may depend on their having control over the presentation of material and on not being sidetracked by the need to respond to countercharges or other diversionary defenses. Thus, in some circumstances a right of access may interfere with the partisan efforts of news organizations to awaken the public conscience to the abuse of power by officials.

Blasi, supra note 20, at 624; see Bezanson, supra note 19, at 620. But see Blasi, supra note 20, at 625-27 (access by individuals who are not public officials promotes the checking value).

48. Blasi, supra note 20 , at 625 .

49. Id. 624; see A. BICKEL, THE MORALITY OF CONSENT 87 (1975).

50. Blasi, supra note 20 , at 624 .

51. See text accompanying note 127 infra; see Siebert, infra note 56, at 29.

52. See Barron, supra note 19, at 1667-78; Nimmer, supra note l, at 645 . 
contributes to the rationale for the independence principle, yet they are two distinct principles. ${ }^{53}$ In resolving any problem in a way consonant with libertarian ideals, one or the other may predominate. ${ }^{54}$ Whereas the independence principle is founded largely on the philosophy of the clecking value, the private-interest principle flows primarily from the libertarian values of individuahisin and self-fulfillment.

The happiness and well-being of the individual are the goals of society, according to libertarian ideology. 55 Libertarian doctrine varies markedly from authoritarianism, ${ }^{56}$ for example, in that the latter subordinates all else to the interests of the state. ${ }^{57}$ Individuals depend on the state to help them attain their full potential as coinponents of a civilized society. ${ }^{58}$ In a libertarian scheine, the state is only a means to individual self-fulfillment. ${ }^{59}$ Individuals may dissolve any bonds that exist between thein and the state when they determine that the state no longer serves their needs. ${ }^{60}$ In sliort, the state derives its authority from the consent of the governed. ${ }^{61}$ The principle of the preeminence of private interests defines the bounds within which the state may exercise its delegated authority. Whether God-given ${ }^{62}$ or utilitarian, ${ }^{63}$ the rights of the individual delimit the extent of the state's power.

53. Indeed, on occasion the principles may dictate conflicting results. See Bezanson, supra note 1, at 765-71. The government's observance of strict neutrality with regard to media news gathering, see id. 754-56,759-62, may be contrary to the private interests of the media. In such cases of conflict, deference to the independence principle may better serve the private interests of the media in the long run. See id. 769.

54. See the discussion of prior restraints at text accompanying notes 82-86 infra.

55. Siebert, supra note 33 , at 40.

56. Authoritarianism has much in common with social-responsibility theory. Siebert, The Authoritarian Theory of the Press, in F. Siebert, T. Peterson \& W. Schramm, Four Theories OF tHe PRESS 28-29 (1956); see J. MERRILL, The IMPERATIVE OF FreEdoM-A PHILOSOPHY OF JOURNALISTIC AUTONOMY 88, $92-93$ (1974).

57. See Siebert, supra note 56 , at 13.

58. See id. 10-11.

59. As Professor Jay Jensen observed, liberalisin conteinplated

a natural opposition between the individual and society, a dichotony which assumed that individuals lave discrete and independent existences apart from the society in which they hve, and which underpinned the "social contract" theory of the time that conceived of society as comprising nothing but an aggregate of individual, autononous wills, and of government as an artifice created by their consent and for the protection of their rights.

Jensen, Freedom of the Press: A Concept in Search of a Philosophy, in Social Responsibiutry of THE NEWSPRESS 71, 77 (1962); see Siebert, supra note 33, at 40-41.

60. See J. LOCKe, SeCOND TREatise of Civil GOVERnMent, supra note $16, \S 1$, at 338; $\S 149$, at $426-27 ; \S 222$, at $469-71 ; \S \S 228-229$, at $473-74$.

61. See id. $\$ \S 96-97$, at 395 .

62. See id. $\S \S 6-7$, at $341-42 ; \S 135$, at 418 .

63. See J.S. MiLL, supra note 19, at 76: "In proportion to the development of his individuality, each person becomes more valuable to himself, and is, therefore, capable of being more valuable to others." See id. 141. But see notes 71-75 infra and accompanying text. 
In its fledgling state, there seemed to be a logical inconsistency in a liberal philosophy that empowers the state to act "whither the greater force carries it, which is the consent of the majority" 64 but that preserves a realm of individual rights supposedly immune from state interference. John Stuart Mill later resolved this conundrum-at least for libertarians-by deferring to individual rights and decrying the "tyranny of the majority." 65

Mill acknowledges an area within which the state may legitimately act on behalf of the public interest, ${ }^{66}$ but he clearly evinces a disdain for the potentially generous breadth of arguments that advance "social rights":

So monstrous a principle is far more dangerous than any single interference with liberty; there is no violation of liberty which it would not justify; it acknowledges no right to any freedom whatever, except perhaps to that of holding opinions in secret, without ever disclosing them; for the moment an opinion whicl I consider noxious passes anyone's lips, it invades all the "social rights" attributed to ine by the Alliance. The doctrine ascribes to all mankind a vested interest in each other's inoral, intellectual, and even physical perfection, to be defined by each claimant according to his own standard. ${ }^{67}$

64. J. Locke, SeCOND TREaTise of Civil Government, supra note 16, § 96, at 395 (emphasis deleted); see A. Stroll \& R. PopkIn, Introduction to Philosophy 198 (2d ed. 1972). One author even asserts that Locke posited "a definition of political power so authoritarian and collectivist in its bearing that no genuine individualist (e.g., Rousseau) could conceivably accept it." W. KENDALL, supra note 29, at 66 .

65. J.S. MiLL, supra note 19, at 6-7.

The limitation, therefore, of the power of government over individuals loses none of its importance when the holders of power are regularly accountable to the community, that is, to the strongest party therem. . . . [I]n political speculations "the tyranny of the majority" is now generally included among the evils against whicls society requires to be on its guard.

Id. See also The Federalist No. 10 (J. Madison) (favoring a republic over a true democracy). Mill even criticized resort to "the moral coercion of public opinion" when it intruded on the legitimate exercise of individual rights. See J.S. MILI, supra note 19, at 13.

66. See J.S. MiLL, supra note 19, at 67-68, 92.

A person should be free to do as he likes in his own concerns, but he ought not to be free to do as he likes in acting for another, under the pretext that the affairs of the other are his own affairs. The State, while it respects the liberty of each in what specially regards himself, is bound to mamtain a vigilant control over his exercise of any power which it allows lim to possess over others.

Id. 127.

67. Id. 109-10. It would be incorrect, however, to characterize Mill as unalterably opposed to governmental impingement of individual liberty. When the exercise of liberty takes the form of action rather than opimion, governmental restraint is more tolerable. J.S. MILL, supra note 19, at 67. Mill's perspective las the eannarks of Justice Holmes's clear and present danger test, see Schenck v. United States, 249 U.S. 47, 52 (1919), which has been criticized as offering too little protection for expression. See, e.g., L. TRIBE, AmERICAN ConstrTutional Law 611 (1978); Blasi, supra note 20, at 647-48 ("A nagging paradox of First Amendment theory is that speech advocating crime or revolution is protected only so long as it is ineffective; this is what the clear and present danger test is all about"); Emerson, Toward a General Theory of the First Amendment, 
Libertarian theory appears to assume ${ }^{68}$ that individuals, possessed of the liberty of expression, will avail themselves of their freedom; ${ }^{69}$ that, rightly or wrongly, mdividuals will espouse their sentiments im a "free and open encounter" out of which participants will discern the truth.70 Mill seemingly grounds his defense of individual liberty of expression on the beliefs that truth would be distilled and tested in an unfettered exchange of ideas and that free individual expression thus evinces social utility. ${ }^{71}$ But Mill goes beyond social utility in defending individual expression. He identifies "absolute freedom of opinion and sentiment" as "almost of as inucl importance as the liberty of thought itself and restimg im great part on the same reasons, [and thus] practically inseparable from it."72

For liberty of expression to be considered in the same breath as liberty of thought is no inconsequential comparison. Surely liberty of

72 YALE L.J. 877, 910-12 (1963) (test allows only innocuous expression and is vague and impossible to administer faithfully); Meiklejohn, The First Amendment and Evils that Congress Has a Right to Prevent, 26 IND. L.J. 477, $477-78$ (1951); Strong, Fifty Years of "Clear and Present Danger": From Schenck to Brandenburg-and Beyond, 1969 SuP. CT. REv. 41, 41-44.

It is clear that Mill did not contemplate absolute protection of liberty from governmental restraint, especially when the individual affects others. See J.S. MiLL, supra note 19, at 13, 68, 92. It may be more correct to characterize Mill as objecting to "excesses of governmental intervention." Shields, Introduction to J.S. MiLl, supra note 19, at xix (einphasis in original). Dean Jerome Barron observed that Mill's "writing reveals that, although the power le knew was government, it was fear of power more than fear of government which animated his thought." J. BARRON, FREEDOM OF THE PRESS FOR WHOM? 82 (1973).

In the final analysis, although Mill indeed may have approved the legitimacy of some measure of state control over the individual, he clearly placed the presumption in favor of individual interests and imposed the burden on the state to prove the nccessity of interference with those imterests. See A. Stroll \& R. PopkIn, INTROduction to PHILOSOPHY 202 (2d ed. 1972).

[T] he sole end for which mankind are warranted, individually or collectively, in interfer$\mathrm{mg}$ with the liberty of action of any of their number is self-protection. That the only purpose for which power can be rightfully exercised over any inember of a civilized community, against his will, is to prevent harm to others. His own good, either physical or moral, is not sufficient warrant.

J.S. MitL, supra note 19, at 13.

68. Indeed, the theory may impose an obligation to speak.

69. See Whitney v. California, 274 U.S. 357, 375 (1927) (Brandeis, J., concurring); Peterson, supra note 26 , at 99 .

70. See note 21 supra. There may also be an assumption that the ideas are available to the persons who actively seek them and are able to compreliend them. Thomas Jefferson, for example, is often quoted as declaring that "were it left to me to decide whether we shonld have a government without newspapers or newspapers without government, I shonld not hesitate to prefer the latter." Letter froin Thomas Jefferson to Edward Carrington (Jan. 16, 1787), reprinted in part in INTERPRETATIONS OF JOURNALISM 52 (F. Mott \& R. Casey eds. 1937). But in a statement of perhaps greater significance, he added that "every man should receive those papers $\&$ be capable of reading them." Id; see Letter from Thomas Jefferson to Charles Yancey (Jan. 6, 1816), reprinted in 14 The Writinas of Thomas JefFerson 384 (Definitive ed., A. Bergh cd. 1907) ("Where the press is free, and every man able to read, all is safe").

71. See J.S. Mill, supra note 19, at 64 .

72. Id. 16 ; see id. 18. 
thought must be the last bastion of security from societal intrusion. ${ }^{73}$ For Mill the societal good is ultimately defined as the sum of all individuals' benefits. Mill's defense of a single individual's freedom to disagree with an opinion held by "all mankind minus one" evinces a solicitude for the interests of that lone dissenter that does not extend to the invocations of the social utility of dissent.74 "The press" is a misnomer in this libertarian scheme. The press should be viewed not as a public institution, but as a group of individuals each having a point of view to sell in the marketplace of ideas. The preeminence of private interests and its meaning for the press perhaps is best summarized in these thoughts of William Peter Hamilton of the Wall Street Journal: "A newspaper is a private enterprise owing nothing whatever to the public, which grants it no franchise. It is therefore affected with no public interest. It is emphatically the property of the owner, who is selling a manufactured product at his own risk."75

\section{See text accompanying note 67 .}

Every freeman has an undoubted right to lay what sentiments he pleases before the public: to forbid this, is to destroy the freedom of the press: but if he publishes what is improper, mischievous, or illegal, he must take the consequence of his own temerity. . . . Thus the will of individuals is still left free; the abuse only of that free will is the object of legal punishment. Neither is any restraint hereby laid upon freedom of thought or inquiry: liberty of private sentiment is still left; the disseminating, or making public, of bad sentiments, destructive of the ends of society, is the crime which society corrects.

4 W. Blackstone, Commentaries *152 (emphasis added).

74. Mill identified benefits to the individual wholly apart from those accruing to the society. See J.S. MiLI, supra note 19, at 45 (benefits to the individual of knowing the truth); id. 82 (of cultivation of higher life); id. 93, 100-02 (in directing one's own life); id. 133-34 (of spurning state intervention even when the aim is to help rather than to hinder). See generally G. SABINE, A History of Polmital THEORY 708.09 (rev. ed. 1950). Professor Thomas Emerson elaborated on this theme when he noted that

it is not a general measure of the individual's right to freedoin of expression that any particular exercise of the right may be thought to promote or retard other goals of the society. The theory asserts that freedom of expression ... . is a good in itself, or at least an essential element in a good society.

T. EMERSON, supra note 19 , at 8.

75. Quoted in Peterson, supra note 26, at 73. Press pundit A.J. Liebling expressed a similar sentiment in a more blunt fashion: "Freedom of the press is guaranteed only to those who own one." Liebling, Do You Belong in Journalism, in THe PREss 30 (1961) (parentheses omitted). See Umited States v. Associated Press, 52 F. Supp. 362, 376-77 (S.D.N.Y. 1943) (Swan, J., dissenting) (busmess of gathering news not recognized at common law as affected with a public interest), affd, 326 U.S. 1 (1945); cf. Munn v. Illinois, 94 U.S. 113, 140-41 (1877) (Field, J., dissenting) (because the public has an interest in a busimess-imcluding the publishimg business-does not clothe that busimess with a public interest). But see Barron, Access to the Press-A New First Amendment Right, 80 HARv. L. Rev. 1641, 1666 (1967); Media and the First Amendment in a Free Society, 60 GEO. L.J. 867, 906-07 (1972).

The framers of the Constitution accorded individuals inaximum freedom to pursue their private interests through expression because they regarded freedoin of the press "as a more or less absolute right, a bberty subject only to individual reason and conscience and to the minimal post- 
3. Implementation of libertarian principles. The libertarian principles of independence froin government and preeminence of private interests pervade United States Supreine Court opinions concerning the first amendment rights of the media. ${ }^{76}$ The principles often coinplement each other, yet one or the other can be seen as governing the outcome in any given case. The conflict between the press and governinent can be classified into two categories: cases im which government tries to dictate what must be published and cases im whicl government tries to dictate what may not be published. The independence principle is the more useful one in analyzing the latter cases. For exainple, in Grosjean v. American Press Co. ${ }^{77}$ Louisiana inuposed a tax on newspapers with circulations over 20,000 in the hope that the state's largest newspapers, critical of Governor Huey Long, would be silenced. ${ }^{78}$ In striking down the tax, the Court elaborated on the historical abuse of such taxes by the Englisli government in its attempts to subjugate dissi-

publication restraints of a free society composed of autonomous individuals possessing similar and equal rights." Jensen, supra note 59, at 79.

Of course, it may be argued that the self-interest of the newspaper owner indirectly contributes to the common good. Cf. 1 A. SMITH, THE WeAlth of NATIONS 456 (R. Cainpbell, A. Skinner \& W. Todd eds. 1976) (1st ed. London 1776) (book IV, ch. 2 of the first edition) (although not concerned with the societal benefits of frce expression, Smith noted there may be general benefits to society fiowing from the pursuit of self-interest).

76. Indeed, Supreme Court opinions may be one of the last bastions of liberalism; many consider hiberalism to be a concept in crisis. F. WATKINS, supra note 2, at ix; Jensen, supra note 59 , at 75 .

In the hiberalistic quests for "freedom under law," $F$. WATKINs, supra note 2 , at $\mathrm{x}$, a potential paradox nay exist because resort to the law inevitably restricts freedom by delimiting its scope. Professor Alexander Bickel alluded to this characteristic of law when he observed, "Those freedoms which are neither challeuged nor defined are the most secure." A. BICKEL, THE MORALITY OF CONSENT 60 (1975). He added that the press can thus be understood to have been freer before it won the Pentagon Papers case because its freedom from prior restraint by federal fiat had not been tested. The press had an "assumed freedom which appeared limitless because its limits were untried." Id. 61.

Incessant resort to legal institutions is arguably antithetical to the liberal precept that an individual enjoys "a minimum of dependence on the discretiouary authority of his rulers," $F$. WATKINS, supra note 2, at X. See J. MERRILL, supra note 56, at iv (quoting from speech by Judge Learned Hand in New York City in 1944):

What do we mean when we say that first of all we seek liberty? I often wonder whether we do not rest our hopes too much upon constitutions, upon laws and upon courts. These are false hopes; beheve me, these are false hopes. Liberty lies in the hearts of inen and women; when it dies there, no constitution, no law, no court can save it . . . . While it lies there it needs no constitution, no law, no court to save it.

See id. 206; Kalven, The New York Times Case: A Note on "The Central Meaning of the First Amendment," 1964 SUP. CT. REv. 191, 221 ("We are reminded . . . of the arresting problem how much freedom of speech in a legal system must depend on law's conscious distrust of its own processes to make needed discriminations").

77. 297 U.S. 233 (1936).

78. See M. FrANKLIN, supra note 17, at 93 . All but one of the papers affected had strongly opposed the Governor's actions. Id. 
dents. ${ }^{79}$ Justice Sutherland, writing for the Court, relied heavily on the checking value ${ }^{80}$ of free expression, and concluded that the imposition of a financial burden by government may inhibit criticism of "misgovernment."81

The issue in all cases of prior restraint-however subtle government's restraint may be-can be characterized as follows: does the government or the speaker determine whether information will be disseminated? ${ }^{82}$ In this context, the primciple of the preeminence of private imterests over public interests is important because it denies government its most powerful justification for the right to decide the issue. The preeminence principle rests, in part, on deference to the individual's interest in speaking. Government's right to subordinate the individual's interest to its own rests on the following premises: first, that government best embodies the public interest; and second, that private imterests should be subordinated to the public interest. ${ }^{83}$ Ac-

79. 297 U.S. at $245-49$.

80. See text accompanyimg note 52 supra. The independence principle may well be the key element of the checking function.

81. 297 U.S. at 250 ; see id. at $246-47$.

82. For example, the result in Smith v. Daily Mail Publishing Co., 443 U.S. 97 (1979), surely did not turn on an analysis of the mterests in the content at issue because such an analysis would compel a conclusion requiring abridgement of the speech. See id. at 107-09 (Rehnquist, J., concurring); Comment, Freedom of the Press vs. Juvenile Anonymity: A Confict Between Constitutional Priorities and Rehabilitation, 65 IowA L. REv. 1471 (1980).

Unlike Landmark Commumications v. Virginia, 435 U.S. 829, 833, 835-36, 838-42 (1978), a similar case that preceded Daily Mail, the Court in Daily Mail did not offer a single interest favoring the dissemmation of a juvenile's name or analyze in any detail the interests favoring restriction of the speech. The only satisfactory analysis of Daily Mail is that the Court, when confronted with the question of whether the government's judgment should be substituted for that of the press, relied on the principle of independence from government in deferring to the press. The principle required that government demonstrate "the highest form of state interest," 443 U.S. at 102; see id. at 103-04, before the insulation between government and press could be breached.

A potential imcursion on the mdependence principle is presented by the mere subinission of disputes to the judiciary-a coordinate branch of government. If "freedom under law," see note 76 supra, is integral to hiberalism, though, some forum is necessary for dispute resolution in which the result is binding. The competence of the courts to fulfill this role "rests upon their independence from other branches of government, their relative immunity to immediate political and popular pressures, the training and quality of their personnel, their utilization of legal procedures, and their powers of judicial review." T. EMerson, supra note 19, at 13.

Upon occasion, however, when the press has felt its independence threatened-as when it perceived itself being used as an investigative arn of government, see Branzburg v. Hayes, 408 U.S. 665, 725 (1972) (Stewart, J., dissenting)-it has evinced a willingness to protect its freedom by relying on its own interpretation of the law. See Blasi, The Newsman's Privilege: An Empirical Study, 70 Mich. L. Rev. 229, 258 (1971). Even subinitting to in camera judicial review may be subject to objection. See New York Times Co. v. Jascalevich, 439 U.S. 1304, 1305 (1978) (in chambers opinion of Marshall, J.). See also J. MerRiLl, supra note 56, at 204.

83. See United States v. Snepp, 456 F. Supp. 176, 182 (E.D. Va. 1978), aff'd in part and rev'd in part, 595 F.2d 926 (4th Cir. 1979), rev'd in part, 444 U.S. 507 (1980) (per curiam). Often it may be more illumimating to view the government as acting in its own interest to prevent release of 
cepting the second premise denies the preeminence principle much of its strength.

Although the principle of preeminence of private interests supplies key support for the imdividual's claim to the right to control his speech, ${ }^{84}$ the independence principle predominates nevertheless. Even if one accepts that the public interest is paramount, few would agree that government was a nionopoly to define this interest. The checking value retains, therefore, much of its vitality. In no other area is the independence of the speaker so crucial or so threatened as when that speaker attempts to address subjects that incur the displeasure of government. ${ }^{85}$ By their very nature, all attempts at prior restraint contravene the principle of independence: the government is second-guessing the speaker's judgment. The interest of the public may or may not accord with the private interest of the speaker, but the independence of the speaker unquestionably is compromised if a prior restraint is

information that is embarrassing. See, e.g., New York Times Co. v. United States, 403 U.S. 713, 724 (1971) (Douglas, J., concurring); United States v. New York Times Co., 328 F. Supp. 324, 330 (S.D.N.Y.), rev'd, 444 F.2d 544 (2d Cir.), rev'd, 403 U.S. 713 (1971) (per curiam); A. BICKEL, THE Morality OF CONSENT 68-69 (1975); cf. United States v. Progressive, Inc., 467 F. Supp. 990, 99395 (W.D. Wis.) (classified information may be compiled from unclassified sources), appeal dismissed, 610 F.2d 819 (7th Cir. 1979). The government has also evinced a sensitivity to criticism, even when the criticisin is unclassified, see United States v. Snepp, 595 F.2d 926, 931 (4th Cir. 1979), rev'd in part, 444 U.S. 507 (1980) (per curiam). See also D. WiSe, ThE Politics of LYING-GOVERnMent Deception, SECRECY, AND POWER 234 (1973).

84. The private interest of the speaker has been pivotal in some prior restraint cases where the public interest might counsel against allowing dissemination of the information. See, e.g., Near v. Minnesota ex rel Olson, 283 U.S. 697 (1931) (publication of scandalous, defamatory inaterial); Wilson v. Superior Court, 13 Cal. 3d 652, 119 Cal. Rptr. 468, 532 P.2d 116 (1975) (publication of material arguably harmful to electoral process). Recognition of a dichotony between prior restraint and subsequent punishment was seen by Blackstone as an appropriate accominodation of the individual interest in expression. See note 73 supra. But cf. 4 W. BLACKstone, CoMmENTARIES 153 n.15 (T. Cooley 3d ed. rev. 1884) (footnote by Cooley) (doubtful whether subsequent criminal prosecutions serve beneficial purpose; excesses of press best restrained by public sentiment and jury awards in libel cases). Blackstone was an ardent advocate of private interests. See D. Boorstin, The MYYsterious Science of THE LAw 162-63 (1941). The dichotomy between prior restraimt and subsequent punishment apparently retains its vitality. See New York Times Co. v. United States 403 U.S. 713, 737 (1971) (White, J., concurring). But see Smith v. Daily Mail Publishing Co., 443 U.S. 97, 101-02 (1979).

85. Professor Blasi chose the following passage as representative of the checking value:

The Government's power to censor the press was abolished so that the press would reunain forever free to censure the Government. The press was protected so that it could bare the secrets of government and inform the people. Only a free and unrestramed press can effectively expose deception in government. And paramount among the responsibilities of a free press is the duty to prevent any part of the government from deceiving the people and sending thein off to distant lands to die of foreign fevers and foreign shot and shell.

New York Times Co. v: United States, 403 U.S. 713, 717 (1971) (Black, J., concurring), quoted in Blasi, supra note 20, at 649. 
imposed. ${ }^{86}$

Perhaps it is not so clear that the independence principle is undermined when the government seeks to confer a benefit rather than to impose burdens. Professor Randall Bezanson argues cogently, however, by analogy to the estabhishment clause of the first amendment, ${ }^{87}$ that even attempts by government to facilitate expression may have several deleterious consequences for press independence. Such attempts may engender fear that what is given may be withdrawn, ${ }^{88}$ may enable government to oversee the press's use of the privilege, 89 and may foster a symbiotic relationship between press and government that would deter full investigation. 90 Bezanson notes that "any special governmental assistance for the press may undermine [the press's] credibility."91 It would have been detrimental to the press, he suggests, to have gained the testimonial privilege it sought in Branzburg v. Hayes, ${ }^{92}$ because the privilege would have been a special governmental benefit not enjoyed by the public at large. ${ }^{93}$ Conferral of such benefits ${ }^{94}$ poses an insidious threat to the independence principle because it creates a role

86. See generally Bezanson, supra note 1, at 762-65.

87. U.S. Const. amend. I; Bezanson, supra note 1, at 732; $g$. L. TRIBE, AMERICAN Const1TUTIONAL LAW $590 \mathrm{n} .8$ (1978) (questioning different analyses of taxpayer suits depending on whether objection is to compel payment of tax for state promotion of speech or for state promotion of religion).

88. The Washington Post editorialized against shield-law legislation for similar reasons. The Problem of "Shield Laws," Wash. Post, Mar. 25, 1974, at A20, col. 1.

89. See Zimmerman, Overcoming Future Shock: Estes Revisited, or a Modest Proposal for the Constitutional Protection of the News-Gathering Process, 1980 DUKE L.J. 641, 701-03; EDITOR AND PUBLISHER, Sept. 13, 1975, at 15.

90. Bezanson, supra note 1, at 734; see $2 \mathrm{Z}$. ChafeE, JR., Government AND MAss CoMmuNICATIONS 475-77 (1947). Chafee notes that the risks of affirmative governmental activity include unintended, ancillary effects that may be counter-productive, the potential for governmental discrimmation in deciding who is to reap the benefits of its largesse, and the tendency of government to increase its influence by increasing the scope of its intervention. Id.

The common practice of leaking information to reporters, as described by Charles Peters, editor of The Washington Monthly, can be understood as a benefit conferred at a price. A symbiotic relationship forms because the publication of information can benefit both the reporter and the source. See C. Peters, How Washington Really Works 25.26 (1980). Peters notes, however, that "[t]his kind of imterdependence weakens a reporter's objectivity and heightens his susceptibility to manipulation." Id. 26. The potential for manipulation exists with nongovernmental sources as well, but their motives seem to be beyond the purview of a constitutional amendinent designcd to limit government conduct. See Branzburg v. Hayes, 408 U.S. 665, 730 (1972) (Stewart, J., dissenting). But see id. at 691 (White, J.).

91. Bezanson, supra note 1, at 734 .

92. 408 U.S. 665 (1972).

93. Bezanson, supra note 1 , at 761 .

94. The independence of the press as defined in Bezanson's analysis was also at issue in KQED, Inc. v. Houchins, 546 F.2d 284 (9th Cir. 1976), rev'd, 438 U.S. 1 (1978), see Bezanson, supra note 1, at 769, as well as in Saxbe v. Washington Post Co., 417 U.S. 843 (1974) and in Pell v. Procunier, 417 U.S. 817 (1974). 
for government in a process that should be as free as possible from government influence.

John Stuart Mill expressed similar reservations when he addressed government intervention on behalf of individuals. He objected to such governmental interference because generally government is more inept than private enterprise ${ }^{95}$ and because the diversity of individual contributions would be stifled by a pervasive, monolithic influence. ${ }^{96}$ But a "third and inost cogent reason" for maintaining independence from government, even when it proffered a benefit rather than a burden, is the great evil of adding unnecessarily to its power. Every function superadded to those already exercised by the government causes its influence over hopes and fears to be inore widely diffused, and converts, more and more, the active and ambitious part of the public into hangers-on of the government, or of some party which aims at becoming the government. If the roads, the railways, the banks, the insurance offices, the great joint-stock companies, the universities, ${ }^{[97]}$ and the public charities were all of them branches of the government ... not all the freedom of the press and popular constitution of the legislature would make this or any other country free otlerwise than im name. ${ }^{98}$

Moreover, in cases in which the government seeks to bestow a right on the press, often a new duty may be imposed as well. ${ }^{99}$ If the press accepts a riglit the public does not have, unost often one may infer a duty of the press to act on behalf of the public when exercising the newly bestowed right. The cases in which the government seeks to impose and to enforce a "public duty" on the press-in most instances a duty to print information-are best analyzed as determined by the primciple of the preeminence of private rigltts.

Although both government and publisher can rely on public-interest arguments to buttress their positions in a case of prior restraint, the public interest is ahgned more clearly against the pubhsher in resolving prepublication questions of compelled access. ${ }^{100}$ The contribution of the private interest to the result is delineated more starkly when the publisher asserts a right not to speak rather than a right to speak. Thus, Chief Justice Burger, writing for the Court in Miami Herald Publishing

95. J.S. MiLL, supra note 19, at 133 .

96. Id. 133-34.

97. See generally Moynihan supra note 35 , at 31 .

98. J.S. MILL, supra note 19, at 134-35. Jose Ortega y Gasset elaborated on a similar theme when he noted that the greatest danger to mass civilization is the tendency to demand that the state intervene and undertake the solution of all problems witl its "immense and unassailable resources." J. ORTEGa y Gasset, The Revolt of the MASSES 132 (1932).

99. See notes 287-89 infra and accompanying text.

100. See Barron, supra note 19, at 1654-55, 1678; Lange, The Role of the Access Doctrine in the Regulation of the Mass Media: A Crilical Review and Assessment, 52 N.C.L. REv. 1, 9 (1973). 
Co. v. Tornillo, ${ }^{101}$ forthrightly set out these private interests: "The power of a privately owned newspaper to advance its own political, social, and economic views is bounded by only two factors: first, the acceptance of a sufficient number of readers-and hence advertisersto assure financial success; and, second, the journalistic integrity of its editors and publishers." "102

In a more abstract sense, the private interest of the newspaper is the self-fulfillment that the Miami Herald gains in communicating its assessment of a candidate for public office. The editors of the Miami Herald can use their forum to wage a vigorous campaign for a course of action that they believe is in the best interest of themselves and the community, secure in the knowledge that their forum will not be a vehicle for contrary, and what they may consider ill-conceived, ideas. ${ }^{103}$ Pat Tornillo may have been the best candidate, but at issue in Miami Herald was the newspaper's right to urge otherwise-without contradiction in its own columns. In a unanimous opinion the Court concluded that, for better or worse, the exercise of editorial judgment is best left within private control. ${ }^{104}$ Chief Justice Burger adverted to the potential for abuse if publishers are left to pursue their private interests, ${ }^{105}$ but rejected the alternative ${ }^{106}$ as in the long run even more detrimental to first amendment values. ${ }^{107}$

101. 418 U.S. 241 (1974). The Court in Miami Herald can be viewed as having acted on the independence principle in holding unconstitutional a governmental atteinpt to facilitate individual expression by mandating access to newspapers. Individuals seeking access to sucl forums inay be better off in the long run if the government refrains from cloosing specific causes to promote. lf the government is to "force a newspaper to print copy which, in its journalistic discretion, it chooses to leave on the newsroom floor," id. at 261 (White, J., concurring), the burden imposed on the press further contravenes the independence principle. The principle that receives substantial emphasis in Miami Herald, however, involves the preeminence of private interests.

102. 418 U.S. at 255 (quoting CBS v. Democratic Nat'l Comm., 412 U.S. 94, 117 (1973) (plurality opinion)).

103. See note 47 supra.

104. 418 U.S. at 258.

105. Id. at $248-54$.

106. Id. at 254.

107. Id. at 257; see id. at 259-61 (White, J., concurring).

For better or worse, editing is what editors are for; and editing is selection and choice of material. That editors-newspaper or broadcast-can and do abuse this power is beyond doubt . . . . Calculated risks of abuse are taken in order to preserve higher values. The presence of these risks is nothing new; the authors of the Bill of Rights accepted the reahity that these risks were evils for which there was no acceptable remedy other than a spirit of moderation and a sense of responsibility - and civility-on the part of those who exercise the guaranteed freedoms of expression.

CBS v. Democratic Nat'l Comm., 412 U.S. 94, 124-25 (1973). Bezanson's analysis of developments in libel revealed libertarian principles as controlling, see Bezanson, supra note 1, at 740-51, although his analysis was for the purpose of distimguishing the speech and press clauses. See id. 748-5l. 


\section{B. Social-Responsibility Theory of the Press.}

Although the social-responsibility theory's origins are diverse, 108 the report of the Commission of Freedom of the Press published in $1947^{109}$ is the theory's key treatise and marks the birth of the theory. ${ }^{110}$ Heavily criticized by the press, ${ }^{111}$ the report, also known as the Hutchins Commission Report, has had an increasingly significant, albeit subtle, impact on the press and on society. ${ }^{1 \text { iz }}$

The arguments favoring a news-gathering right rely mainly on the need of the public to be inforned. ${ }^{113}$ This need exists because democratic government requires a knowledgeable citizenry if the citizenry is to exercise its franchise in a principled manner. ${ }^{114}$ Proponents of libertarian and social-responsibility theories are in accord on the premise that the maximum flow of infornation is a desirable end, ${ }^{115}$ but they disagree on the means of achieving that end. Libertarians view autonomy from government and emphasis of private interests as inost effective in encouraging expression, but social-responsibility advocates assert that the implementation of those principles has yielded unsatisfactory results. ${ }^{116}$ Freedom of expression is endangered unless libertarian precepts are abandoned, according to the report of the Hutchins

108. Though the report of the Commission on Freedom of the Press and the Commission's other publications were published in the late 1940s, the principles recognized in those publications previously received attention. Considerable pressure on the press to promote society's interests rather than its own had been exerted beginning with the socio-economic reform inovement of the 1930s. See M. BLANCHARD, supra note 1, at 3-9. There are numerous remarks on the relevance of public interests and the rights of the audience in the literature from this period. See United States v. Associated Press, 52 F. Supp. 362, 370-73 (S.D.N.Y. 1943), affd, 326 U.S. 1 (1945); L. BERGREEN, LOOK NOW, PAY LATER-THE RISE OF AMERICAN BROADCASTING 46 (1980) (text of RCA advertisements from 1926); H. ICKES, AMERICA's HOUSE OF LORDS 160, 162-63, 166 (1939); Booth, The Freedom of the Press, in ONE HuNDRED AND FIFTIETH ANNIVERSARY OF THE WorCester FIRE SocIETY 16, 19 (1943); Ernst, Freedom to Read, See, and Hear, HARPER's MAG., July 1945, at 51.

109. Commission on Freedom of the Press, A Free and Responsible Press (1947) [heteinafter cited as COMMISSION].

110. See Jensen, supra note 59, at 79; Peterson, supra note 26, at 75.

111. H. Nelson, Freedom of the Press from Hamilton to the Warren Court at xlixlii (1967).

112. See M. BLANCHARD, supra note 1, at 51-52. "A chief service of the volume is that it inakes criticism of the press respectable.' " Id. at 48 (quoting Liebling, Review, THE NATION, Apr. 12,1947 , at 427).

113. See Saxbe v. Washington Post Co., 417 U.S. 843, $862-64$ (1974) (Powell, J., dissenting); Branzburg v. Hayes, 408 U.S. 665, 725-27 (1972) (Stewart, J., dissenting).

114. See BeVier, supra note 43 , at 482 .

115. Compare J.S. MlLL, supra note 19, at 64 and note 21 supra with CoMmission, supra note 109, at 36 (more information, not less, is the optimum).

116. See Commission, supra note 109, at 15-17; W. Rivers, W. Schramm \& C. Christians, Responsibility in Mass Communications $44-45$ (3d ed. 1980); Peterson, supra note 26, at 74, 78-79. 
Commission. ${ }^{117}$ The lack of "positive" freedom ${ }^{118}$ and the selfish aims of powerful, concentrated media have created a climate detrimental to the public in which first amendment values are not beimg realized.119 When a few exercise control over the freedom of speech "im such a way as not to supply the people with the service they require, the freedom of the minority . . . is im danger."120 Social-responsibility advocates caution that government intervention poses its own dangers, but nonetheless they differ markedly from their libertarian counterparts by assigning an "important part" to government in the realization of freedom of expression. ${ }^{121}$ Government may intervene, however, only to facilitate freedom of expression that benefits the public. ${ }^{122}$

1. Government intervention. Self-regulation is the ideal in a social-responsibility scheme, ${ }^{123}$ but according to the Commission, the fruits of self-regulation have been disappointing. ${ }^{124}$ The substantive deficiencies ${ }^{125}$ of the "news" purveyed by inass media demonstrate the fallacy of relying solely on the unregulated initiative of the private sector. ${ }^{126}$ As one cominentator wrote, social-responsibility theory contemplates "some form of control, preferably by the media theinselves with a benevolent government in the background unobtrusively checking the ground rules." 127

117. Commission, supra note 109, at 1-2; see id. 80.

118. See notes 142-54 infra and accompanying text.

119. See Commission, supra note 109, at 1-2.

120. Id. 2 ; see id. $60,80$.

121. Id. 2-3, 4-5, 7-8. See Siebert, The Authoritarian Theory of the Press, in F. SiEBert, T. Peterson \& W. Schramm, Four Theories of the Press 29 (1956). Professor Jensen aptly summarized the distinctive attitudes toward government that characterize theories of liberalism and social responsibility - which he termed "neo-liberalism"-when he noted that although the former "held the state in contempt and fear, the position of neo-Liberalism is that government can and should be both protector and promoter of the freedom of the press." Jensen, supra note 59, at 83; see J. MERRILI, supra note 56, at 37.

122. See Commission, supra note 109 , at $8,18,127$ app.

123. Id. 3, 69, 90-91.

124. Id. 1, 17, 54-62, 103-05, 124 app. Much of the Commission's criticism is qualitative:

[N]eeds are not being met. The news is twisted by the emphasis on firstness, on the novel and sensational; by the personal imterests of owners; and by pressure groups. Too much of the regular output of the press consists of a miscellaneous succession of stories and images which have no relation to the typical lives of real people anywhere. Too often the result is meaninglessness, flatness, distortion, and the perpetuation of misunderstanding among widely scattered groups whose ouly contact is through these media.

... When we look at the press as a whole ... we must conclude that it is not meeting the needs of our society. The Commission believes that this failure of the press Id. 68. is the greatest danger to its freedom.

125. See note 124 supra.

126. Commission, supra note 109 , at 125 app.

127. Siebert, supra note 56, at 29; see Z. CHAFEe, JR., supra note 90, at 547 (Chafee was a member of the Commission); F. SIEBERT, supra note 1, at 12. The faith of social-responsibility 
Government intervention is necessary because the mere absence of restraint is thought inadequate to ensure freedom of expression. ${ }^{128}$ Some modicum of restraint on freedom is necessary to accommodate the exercise of freedoms by others in civil society. ${ }^{129}$ Unlimited freedoin of expression can impinge on rights of privacy, ${ }^{130}$ the right not to hear, ${ }^{131}$ and various other private rights, as well as vital social interests. ${ }^{132}$ But more to the poimt, freedorn of expression is subject to limitation because the freedoun extends only as far as its underlying rationale. ${ }^{133}$ In a social-responsibility scheme, freedom of expression is conditioned on fulfilling a duty to the common good and to one's own thoughts. ${ }^{134}$ The former is shirked if the press provides inadequate or contammated information; ${ }^{135}$ the latter is abdicated if one's expression does not coinport with one's thoughts-that is, if one deliberately hes. ${ }^{136}$ With duties and responsibilities come accountability, and with accountability comes government intervention. ${ }^{137}$

Far from being considered the "chief foe of liberty" as under liber-

theorists in the performance of government is exemplifed by the admonition of the Commission that government "should enter the field of press comment and news supply," and, thus, perhaps "present standards for private emulation." Commission, supra note 109, at 128 app.; see id. 5 n.1, 8. But see id. 4-5.

128. Indeed, one school of philosoplyy loolds that there can be no freedom without restraint. See W. Hocking, supra note 23, at 66-69; R. Perry, Puritanism and Democracy 521-23 (1944).

129. Professor Ralph Barton Perry observed:

The most serious hindrance to a man's interest is the rival interest of his neighbor. Suffering or fearing this hindrance, he must postpone his interest until the hindrance is removed. This is wly war becomes every man's first busimess. It is clear that the only permanent remedy hes in the systematic delimitation of interests. There is a greater liberty to be enjoyed through the acceptance of sucl delimitation than through the unrestrained assertion of a claim of limitlessness.

If this is reasonable, then it is evident to all men in proportion as they are endowed with reason; and they will proceed accordingly to restrain hiberty for the sake of liberty.

R. Perry, Puritanism and Democracy 522 (1944).

130. W. Hocking, supra note 23, at 71 n.14.

131. See Commssion, supra note 109, at 111 app.

132. Peterson, supra note 26, at 97-99; see W. Hocking, supra uote 23, at 112, 120-26.

133. See Commission, supra note 109, at 10; W. HockIng, supra note 23, at 120-26.

134. Commission, supra note 109, at 10; W. HockING, supra note 23, at 109. Hocking posited that only liberty of thought is an unconditional right that is incapable of being abridged because society cannot reach it. W. HockiNG, supra note 23 , at 72 . See also text accompanying notes 72 73 supra. Such a position seems $i$ - ssistent with his views on "positive" freedom in the realm of thought. See W. HockING, supra n..e 23, at 54-55. The need for "means to achicve the end" of thought seems no less when dealing with liberty of thought than when dealing with any other liberty. Professor Perry, for example, noted that the liberty of thought that is "indestructible in its negative aspect is no liberty at all without the capacity to think, and that it is therefore nullified by mental disease, habit, indoctrination, lyysteria, or lack of education." R. PERRY, PURITANISM AND DEMOCRACY 514 (1944).

135. Commission, supra note 109, at 125 app.

136. Id. $10,87$.

137. See id. 125-28 app. 
tarian precepts, ${ }^{138}$ government is the "first line of defense" for press freedom in a social-responsibility setting. ${ }^{139}$ Social-responsibility advocates point out that government is the only entity capable of maintaining the public order, which is a prerequisite to free expression. ${ }^{140}$ Moreover, having overcome much of the suspicion toward government that characterizes libertarian thinking, ${ }^{141}$ social-responsibility theorists assert that government can play a positive role in the field of expression. ${ }^{142}$ Government is called on to ensure that the press is free-as defined in social responsibility terms-to accomplish the ends for which its freedom was intended. ${ }^{143}$

Relying on notions of "positive" as opposed to "negative" freedom, ${ }^{144}$ social-responsibility proponents view government intervention as enabling achievement of true freedom. Just as a child left in the middle of a desert is free from all constramts, but lacks positive freedom to accomplish anything but starvation, ${ }^{145}$ freedom from govern-

Implicit in this trend toward "social responsibility" is the argument that some group (obviously a judicial or governmental one, ultimately) can and inust define or decide what is socially responsible. ...

....

Many persons will object to this line of analysis and will say that "social responsibility" of the press of a nation does not necessarily imply government control. I contend . that ultimately it does, since if left to be defined by various publishers or journalistic groups the term is quite relative and nebulous; and it is quite obvious that in the traditional context of American libertarianism no "solution" that would be widely agreed upon or practiced could ever be reached by non-government groups or individuals.

J. MERRILL, supra note 56, at 91-92.

138. See note 26 supra and accompanying text.

139. Commission, supra note 109, at 115 app. See note 121 supra.

140. Commission, supra note 109, at 114 app.

141. See W. HockInG, supra note 23 , at 11 .

142. The Commission noted that active governmental involveinent is not necessarily antithetical to a systen founded primarily on private enterprise, as exemplified by governmental control of the post office. See Commission, supra note 109, at 81. But see Associated Third Class Mail Users v. United States Postal Serv., 600 F.2d 824, 825 n.3 (D.C. Cir.), cert. denied, 444 U.S 837 (1979); Umited States Postal Serv. v. Council of Greenburgh Civic Ass'ns, 490 F. Supp. 157, 159-61 (S.D.N.Y. 1980), rev'd, 101 S. Ct. 2676 (1981). See also W. HocKING, supra note 23, at 188-89: "The state is, in its nature, the greatest instrument for achieving the common purposes of the human community."

143. See W. HockING, supra note 23 , at 183-84, 197.

144. Peterson, supra note 26, at 93-94; see Commission, supra note 109, at 18-19; A. Meiklejohn, Free Speech and Its Relation to Self-Government 16-17 (1948); Chafee, Freedom of Speech As I See It Today, 18 Journalism Q. 158, 158 (1941). See also I. Berlin, TWo CONCEPTS OF LIBERTY 6-19 (1958).

145. H. Muller, Issues of Freedom: Paradoxes and Promises 7 (1960); see R. Perry, Puritanism AND DEmocracy 525-26 (1944):

If it be the duty of government to promote the liberty of every man within its jurisdiction, this duty inust be construed to embrace positive and not nerely negative liberty. If a man is to do what he desires, wills, or believes to be his duty, le must possess the means, and not merely the permission. . . .

... If you cast a man into stormy waters far from land and tell him that there is nothing to prevent his swimming to shore, there is clearly something lacking in his lib- 
mental restrictions "is now not enough to guarantee that a man who has something to say shall have a chance to say it."146 The state in a social-responsibility scheme is ultimately responsible for adequate press performance. ${ }^{147}$ If no forum exists for citizens to initiate or to join public debate, ${ }^{148}$ then government must remedy the situation. ${ }^{149}$ Likewise, if concentration of media ${ }^{150}$ or other monopolistic tendencies $^{151}$ impair the free flow of information to the public, then government has cause to imtervene, albeit delicately, so as not to impose on the press a liardship that ultimately disserves the public. ${ }^{152}$

The press has no defense to these governmental incursions because under this theory the press has freedom only to fulfil its social responsibilities; ${ }^{153}$ when it ceases fulfilling those responsibilities, its freedom ceases as well. ${ }^{154}$

erty. . . . The man who demands "effective personal freedom" wants to be put on shore to start with.

146. Commission, supra note 109 , at 16. It is incorrect, however, to characterize libertarians as ignorant of the possibilities of positive freedom im expanding imdividual potential. As Watkins noted, "Genume respect for the individual involves a sense of responsibility for the equalization of social opportunities." F. WATKINS, supra note 2, at 250. Mill, for example, saw a role for

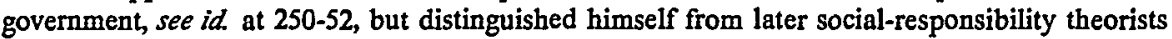
by his concurrent, imtense skepticism of government's predisposition to abuse its power in fulfilling that role. See text accompanying note 98 supra.

147. W. Hocking, supra note 23 , at 182.

148. For discussion of such forums, see Commission, supra note 109, at 23-25; A. MEIRLEJOHN, supra note 144, at 26.

149. See Commission, supra note 109, at 127 app; W. Hocking, supra note 23, at 184-86; A. MEIKLEJOHN, supra note 144, at 16-17.

150. See Commission, supro note 109 , at 17.

151. See W. Hocking, supra note 23, at 171-74.

152. Commission, supra note 109, at 83-85. Iromically, government may itself be the cause of monpolistic or anticompetitive practices. See 1 Monopoly Problems in Regulated Industries: Hearings Before the Antitust Subcomm. of the House Comm. on the Judiciary, 84th Cong., 2d Sess. 6164 (1956) (statement of Marver H. Bernstein); 1 FEDERAL CoMMunications CoMmission NeTWORK INQuiry SPEClal Staff, FiNAL Report-NeW TeleVision NeTWORKS: ENTRY, JuRISDICTION, OWNERSHIP AND REgulAition 5-6, 22 (1980); Coase, The Federal Communications Commission, 2 J.L. \& EcoN. 1, 20-21, 27-28, 38-40 (1959).

153. Of course, in fulfilling its responsibilities, the press's freedom as well as that of the citizens it serves must be supplemented in a positive fashion:

An ideally free press is free for the achievement of those goals of press service which its own instinct of workmanship and the requirements of the community combine to establish; and for these ends it must have command of all available technical resources, financial strength, reasonable access to sources of information at home and abroad, and the necessary staff and facilities for bringing its information and its judganents to the national inarket.

W. HockING, supra note 23, at 195 (emphasis in original).

154. To protect the press is no longer automatically to protect the citizen or the community. The freedom of the press can remain a right of those who pubhsh only if it incorporates into itself the right of the citizen and the public interest.

The press ... must be free for making its contribution to the maintenance and development of a free society. 
2. Public interest. Given that speech under a social-responsibility scheme is subject to regulation, it is the interest of the public that serves as the standard for such regulation. ${ }^{155}$ The right of speech is understood to encompass two rights: that of the audience as well as that of the speaker. ${ }^{156}$ The relevance of the listener's right is implicit, socialresponsibility theorists contend, even under a libertarian theory. "Inseparable from the right of the press to be free has been the right of the people to have a free press," wrote William E. Hocking. 157 "But the public interest has advanced beyond that point; it is now the right of the people to have an adequate press." 158 And of the two rights, it is the right of the public "which today tends to take precedence in importance." 159 This public right is adverted to most commonly in terms of the "public's right to know," 160 which has been urged even by those

This implies that the press must also be accountable. It must be accountable to society for meeting the public need and for maintaining the rights of citizens and the almost forgotten rights of speakers who liave no press. It must know that its faults and errors have ceased to be privatc vagaries and have become public dangers. . . . Freedom of the press for the coming period can only continue as an accountable freedom.

Commission, supra note 109, at 18-19.

155. See id. 8, 18, 127 app.

156. W. HockING, supra note 23 , at 169 . This concept is not foreign to a libertarian interpretation. Indeed, one can question whether allowing speakers to speak but preventing an audience from hearing their words constitutes the exercise of a speecir right. Implicit in the concept of "public" forum is the right of listeners as well as speakers to be free from government regulation. See Tinker v. Des Moines Indep. Comınunity Sclıool Dist., 393 U.S. 503, 513 (1969); Schneider v. State, 308 U.S. 147, 162 (1939); Hague v. CIO, 307 U.S. 496, 515 (1939) (opinion of Roberts, J.), quoted with approval in Kunz v. New York, 340 U.S. 290, 293 (1951); Cass, supra note 20, at 128788; Kalven, The Concept of the Public Forum: Cox v. Louisiana, 1965 SUP. CT. REv. 1, 11-12. Likewise, unwarranted intrusions on the listeners have been thought sufficient to restrict the rights of speakers. See Rowan v. Post Office Dep't, 397 U.S. 728, 736-37 (1970); Kovacs v. Cooper, 336 U.S. 77, $87-89$ (1949); Black, He Cannot Choose But Hear: The Plight of the Captive Auditor, 53 CoLUm. L. Rev. 960 passim (1953). Compare Southeastern Promotions, Ltd. v. Conrad, 420 U.S. 546, 555-56 (1975) with Lehman v. City of Slaker Heights, 418 U.S. 298, 302, 304 (1974) (opinion of Blackmun, J.). But see Colien v. California, 403 U.S. 15, 21-22 (1971). At the very least, the first amendment right of assembly can be viewed as the audience's corollary to the freedoms of speech and press. C. Richmond Newspapers, Inc. v. Virginia, 448 U.S. 555, 577 (1980) (right of asseinbly a "catalyst" for other first amendment rights).

157. W. HockINo, supra note 23, at 169. Professor Hocking was a member of the Commission on Freedom of the Press, and the Commission relied lieavily on his contributions. See J. Gerald, The Social Responsibility of the Press 164 (1963).

158. W. HocknNG, supra note 23 , at 169 (empliasis in original).

159. Id

160. See Peterson, supra note 26, at 73. See generally H. Cross, The People's Right to KNOW (1953); C. WHALEN, JR., YouR RIGHT TO KNOW (1973); Emerson, Legal Foundations of the Right to Know, 1976 Wash. U.L.Q. 1; Goodale, Legal Pitfalls in the Right to Know, 1976 WASH. U.L.Q. 29; Hennings, Constitutional Law: The People's Right to Know, 45 A.B.A.J. 667 (1959); Horton, The Public's Right to Know, 3 N.C. CENT. L.J. 123 (1972); Kutner, Freedom of Information: Due Process of the Right to Know?, 18 CATH. LAw. 50 (1972); Mardian, What Should the People Know?, Trial Mar.-Apr. 1972, at 16; Parks, The Open Government Principle: Applying the Right to Know Under the Constitution, 26 GEo. WaSH. L. REv. 1 (1957); Philos, The Public's Right 
whose private interests are subordinated. ${ }^{161}$ Press owners' and practitioners' advocacy of the public's right to know according to Professor Jay Jensen

may in some cases be merely an attempt to safeguard their enjoyment of press freedom as a personal right under the guise of a concern for a public right. Still, their shift in emphasis froin an individual to a collective right, whether a public relations strategy or not, is widespread and illustrates the continuing collectivization of the ineaning and status of freedom of the press as a right. ${ }^{162}$

Keeping foremost the ideal of self-regulation, ${ }^{163}$ social-responsibility proponents pay lomage to libertarian principles by recognizing that, in general, protection of the right of the speaker or publisher suffices to serve the public interest. ${ }^{164}$ Indeed, these essentially individualistic sources of thought should not be unduly hampered. ${ }^{165}$ To do so

to Know and the Public Interest-A Dilemma Revisited, 19 FED. B.J. 41 (1959); Rogers, The Right to Know Government Business from the Viewpoint of the Government Official, 40 MARQ. L. REV. 83 (1956); Wiggins, The Role of the Press in Safe-Guarding the People's Right to Know Government Business, 40 MÁrQ. L. Rev. 74 (1956); Yankwich, Legal Implications of, and Barriers to, the Right to Know, 40 Marq. L. Rev. 3 (1956); Note, The Constitutional Right to Know, 4 Hastinas Const. L.Q. 109 (1977); Note, Access to Government Information and the Classification Process-Is There a Right to Know?, 17 N.Y.L.F. 814 (1971); Note, The Right to Know in First Amendment Analysis, 57 TEX. L. Rev. 505 (1979); Comment, National Security and the Public's Right to Know: A New Role for the Courts Under the Freedom of Information Act, 123 U. PA. L. REv. 1438 (1975).

Kent Cooper of the Associated Press coined the phrase "the people's right to know" in 1945, using it in talks and articles as a rationale for facilitating international communications. "The Right to Know," N.Y. Times, Jan. 23, 1945, at 18 (editorial); see Peterson, Social Responsibility Thirty Years after the Hutchins Commission 12-13 (unpublished enanuscript in author's possession at the University of Illinois).

161. J. WIGGINS, FREEdOM OR SECRECY passim (rev. ed. 1964); Society of Professional Journalists, Sigma Delta Chi, Code of Ethics, QuiLl, Sept. 1980, at 29, reprinted in M. FrankLiN, supra note 17, at 716 app. C; see D. PEMBER, MASS MEdiA LAW 438-39 (1977); cf. Cronkite, Introduction to C. WHALEN, JR., YOUR RIGHT TO KNOW at X (1973) (freedom of the press is a right of the American public); Sulzberger, The Newspaper-Its Making and Meaning, in 11 V1TAL SPEECHES 539, 541 (1945) (press freedom is people's freedoin).

162. Jensen, supra note 59 , at 81 . Individuals cannot be faulted for adopting a collective perspective that pervades societal attitudes. To relate to their society, individuals' thetoric may reficct collectivisin although their ideology reinains individualistic. The dilemma thus poscd, of course, is whether an individualist, liberal orientation can be reinforced or even retaincd wlien its advocates actually advocate a different philosophy, perhaps even unwittingly. The rhetoric may reshape the philosophical orientation. Press owners and practitioners may come to see themselves as having

reality and ineaning only in the collectivity of culture and in relation to other culturally determined selves. In short, the "autonomous" self is being replaced by the "cultural" self; and the effects of this displaceinent are visible not only in contemporary life and thought in general, but in definition and status of freedoin of the press in particular.

Id. 78; see id. 78-81. See note 108 supra.

163. See note 123 supro and accoinpanying text.

164. See CoMmission, supra note 109, at 112; Peterson, supra note 26, at 74.

165. W. Hocking, supra note 23, at 169 n.7; see CoMMIssion, supra note 109, at 111-12 app., 125 app. 
would ultimately disadvantage the public who would not have the benefit of diverse ideas from which to choose its policies of selfgovernment. ${ }^{166}$

It is apparent im the social-responsibility context, however, that although giving every imdividual the most opportunities to speak may represent the optimum, ${ }^{167}$ it is essential "not that everyone shall speak, but that everything worth saying shall be said." 168 In a phrase that can well be the credo of the social-responsibility advocates, Alexander Meiklejohn sliced to the core of the public-interest principle when lee noted that "the poimt of ultimate interest is not the words of the speakers, but the minds of the hearers." 169

The press is free to be accurate, ${ }^{170}$ to convey all ideas deserving of a public hearing, ${ }^{171}$ and to educate the public. ${ }^{172}$ Extrapolating from these basic mandates, a social-responsibility proponent contemplates public access to the media, ${ }^{173}$ and compulsory expression ${ }^{174}$-including

166. A. MEIKLEJOHN, supra note 144, at 26-27. The checking function, which is crucial to the libertarian principle of nonregulation, see notes 34-52 supra and accompanying text, is distinct from the value of free expression in promoting self-government. See Blasi, supra note 20, at 55467.

167. Meiklejohn proposes that protection be absolute in the case of political speecl. See A. MeIKLejohn, supra note 144, at 35-39; Meiklejohn, The First Amendment Is An Absolute, 1961 Sur. CT. REv. 245, 255. He qualifies that "absoluteness," however, with rules of etiquette, A. MEIKLEJOHN, supra note 144, at 22-24, and the condition that views expressed be "responsibly entertained." Id, at 27. Professors Kalven and Karst both point out that Meiklejohn's townmeeting example, $i d$. at $22-25$, oversimplifies the practical problems in implementing the philosophy. See Kalven, supra note 156, at 26; Karst, supra note 20, at 40.

168. A. MEIKLEJOHN, supra note 144 , at 25 . Hocking notes that censorship is appropriate to prevent "diseducation" from speech that is only of negative worth because it degrades and causes "the slow unbalancing of emotion in the accepting mind, the disintegration of personality, the decay of taste, the gradual confirmation in the individual case of the lyypothesis put before him that man is an animal-and nothing else." W. HockING, supra note 23, at 191-93.

169. A. MEIKLEJOHN, supra note 144, at 25; CBS v. Democratic Nat'l Comm., 412 U.S. 94, 122 (1973) (quoting A. Meikiejohn, Political Freedom 26 (1948)); see Z. Chafee, JR., supra note 90, at 546; Commission, supra note 109, at 23-24. But see Z. CHAFEE, JR., supra note 90, at 69596. The Supreme Court eudorsed the principle as apphed to the electromic media in Red Lion Broadcasting Co. v. FCC, 395 U.S. 367 (1969). "It is the right of the viewers and listeners, not the right of the broadcasters, which is paramount." Id at 390 . One commentator has noted that the sentence is pregnant with future possibilities. Powe, "Or of the [Broadcast] Press," 55 TEx. L. REv. 39, 46 (1976).

170. Sce Commission, supra note 109, at 21-23, 120-21 app. Of course, the press is not expected to be infallible and inadvertent error is condoned in the name of encouraging speech. See id. 121-22 app.

171. See id. 23-25, 28, 129 app; W. HockING, supra note 23, at 98.

172. Commission, supra note 109 , at 26-28.

173. Id. 23-24, 129 app.; Barron, Access to the Press-A New First Amendment Right, 80 HARv. L. REV. 1641, 1654-56, 1658-60, 1666, 1678 (1967). The Commission regarded the media as "coinmon carriers of public discussion," but was quick to qualify its choice of words by noting that it did not mean to imply compulsory access for all applicants. Commission, supra note 109, at 23 \& n.1. Although the Commission downplayed the governmental role, Barron was unambiguously 
disclosure of sources of information ${ }^{175}$ and identities of authors ${ }^{176}$-so the public can more reliably judge the veracity of information it receives.

3. Implementation of social-responsibility principles. Commercial speech is the paradigm of the implementation of the social-responsibility principle of speech regulated in the public interest. Regulation of commercial speech antedates application of the public-interest principle. Indeed, imitially regulation was condoncd to protect the private interests of business competitors. ${ }^{177}$ It was argued that, without regulation of false or deceptive claims, an unfavorable diversion of trade would disadvantage the interests of scrupulous advertisers. ${ }^{178}$ The prospect of government regulation undoubtedly appealed to honest advertisers who would be frce to direct their marketing resources to more positive uses than correcting the misinformation disseminated by competitors. ${ }^{179}$

Regulation in furtherance of private imterests is acceptcd inost by speakers whose interests are furthered. ${ }^{180}$ As libertarians might have predicted, however, government sought to increase the scope of its regulation, ${ }^{181}$ which im turn increased the number of private imterests ad-

frank in stating that government necessarily is the ultimate arbiter of access. Barron, supra at 1667-78.

174. Commission, supra note 109 , at 124 app.

175. Id 25.

176. W. HocknNG, supra note 23, at 187. Chafee agreed for the most part, but he had reservations concerning the practical aspects of implementation. Z. CHAFEe, JR., supra note 90, at 48788.

177. See FTC v. Raladam Co., 283 U.S. 643, 650, 652-53 (1931); O. PEASE, THE RESPONSIBILITIES OF AMERICAN ADVERTISING 90 (1958). The advertising trade press eventually expressed its regret that the Federal Trade Commission, "begun as an aid to business, [has] now become an enemy of business in having to imterfere with the natural relations between business and the pubhic." O. PEAse, supra, at 91.

178. See FTC v. Algoina Lumber Co., 291 U.S. 67, 72 (1934); FTC v. Winsted Hosiery Co., 258 U.S. 483, 493-94 (1922).

179. The inotivations and rationales for advertising are set out in detail in Brown, Advertising and the Public Interest: Legal Protection of Trade Symbols, 57 YALE L.J. 1165, 1167-83 \& n.10 (1948).

180. See B. Schwartz \& H.W.R. WAdE, Legal Control of Government-AdMinistrative LaW In Britain and the United States 33 (1972); 1 Federal CoMmunications CoMMISSION NETWORK INQUIRY STAFF, FINAL REPORT-New Television NETwORKS: ENTRY, JURISDICTION, OWNERSHIP AND REgulation 21-22 (1980). See generally 1 Monopoly Problems in Regulated Industries: Hearings Before the Antitrust Subcomm. of the House Comm. on the Judiciary, 84th Cong., 2d Sess. 61, 64 (1956) (statement of Marver H. Bernstein); M. EdelMAN, THE SyMbolic Uses of Politics 24, 56-58 (1964).

181. See note 29 supra and accoinpanying text. Justice Douglas, in his inimitable inanner, touched on this penchant of government to expand its authority when he posed the "caunel's nose in the tent" inetaphor. The FCC's fairness doctrine, Douglas wrote, "puts the head of the camel inside the tent and enables administration after administration to toy with TV or radio in order to 
versely affected.182 With the passage of the Wheeler-Lea Amendments to the Federal Trade Commission (FTC).Act, ${ }^{183}$ the FTC was given the authority to regulate on behalf of consumers as well as commercial speakers. ${ }^{184}$ The power of the FTC to act in the public interest lias continued to grow. ${ }^{185}$ The significance, in constitutional terms, of this

serve its sordid or its benevolent ends." CBS v. Democratic Nat'1 Comm., 412 U.S. 94, 154 (Douglas, J., concurring); see Z. Chafee, JR., supra note 90, at 709-11. The fear is that where the camel's nose goes, so goes the camel. For a thoughtful analysis of this phenomenon, see Bollinger, Freedom of the Press and the Public Access: Toward a Theory of Partial Regulation of the Mass Media, 75 Mirch. L. Rev. 1, 20-22, 31-32 (1976).

Professor Chafee, who served on the Commission for a Free and Responsible Press and who contemplated affirmative governmental action to ensure freedom of expression, $Z$. CHAFEE, $J_{R}$, supra note 90 , at 547, nonetheless warned that such action carries with it the potential for government intervention into the communications process to an impermissible extent. See id. 477, 69496.

182. See A. Bickel, The Morality of Consent 60 (1975).

183. Act of March 21, 1938, ch. 49, § 3, 52 Stat. 111, (amending 15 U.S.C. \& 45(a)(1) (1934)) (codified at 15 U.S.C. \$ 45(a)(1) (1976)).

184. "[T]his amendinent makes the consumer, who inay be mjured by an unfair trade practice, of equal concern, before the law, with the merchant or manufacturer injured by the unfair methods of a dishonest competitor." H.R. REP. No. 1613, 75th Cong., 1st Sess. 3 (1937); see Note, The Consumer and Federal Regulation of Advertising, 53 HARv. L. REV. 828, 834-37 (1940). The Wheeler-Lea Amendments were a legislative response to the decision in FTC v. Raladam Co., 283 U.S. 643 (1931), in which the Court found injury to consuniers irrelevant absent initial proof of injury to competitors. See id at 648-49,653. Until recently, however, regulation on behalf of competitors continued to receive substantial emphasis from the FTC. See Pitofsky, Beyond Nader: Consumer Protection and the Regulation of Advertising, 90 HARv. L. REv. 661, 680 (1977).

It may have been more than coincidence that the social-responsibility theory was eoming into vogue, see note 108 supra, at a time of "burgeoning administrative activity by the federal government in the 1930's." Williams, Fifty Years of the Law of the Federal Administrative Agencies-And' Beyond, 29 FED. B.J. 267, 268 (1970). Five of the "big seven" administrative agencies were established in the 1930s. B. SchwarTz \& H.W.R. WADE, supra note 180, at 28. The standard often used to "guide" this regulatory activity is the public interest. E.g., Communications Act of 1934, ch. 652, tit. III, $\$ \S 303,307$ (a), 309(a), 310(b), 48 Stat. 1081 (codified at 47 U.S.C. $\$ \$ 303,307$ (a), 309(a), 310(b) (1976)). Professors Scluwartz and Wade commented about the application of this standard to the Federal Communications Commission: "In practice, Congress has given the Commission what amounts to carte blanche. Telling the F.C.C. to act in the public interest is the equivalent of telling it: Here is the regulatory problem; deal with it as you choose." B. SCHWARTZ \& H.W.R. WADE, supra note 180, at 32. For further criticism of the public-interest standard, see Coase, supra note 152, at 8-9. "This phrase, taken from public utility legislation, lacks any definite meaning. 1t 'means about as little as any phrase that the drafters of the Act could have used and still comply with the constitutional requirement that there be some standard to guide the administrative wisdom of the Hicensing authority." Id. 8 (quoting Caldwell, The Standard of Public Interest, Convenience or Necessity as Used in the Radio Act of 1927, 1 AIR $\mathrm{L}$. Rev. 295, 296 (1930)). See generally A. BickeI, The Least Dangerous Branch 160-61 (1962).

Given the ambiguity of the standard, the question may fairly be raised whether the standard does little more than thinly disguise governmental attempts to legislate expansion of its authority. To point out that the standard gives the government flexibility in addressing problems, see FCC v. Pottsville Broadcasting Co., 309 U.S. 134, 138 (1940), presames the authority of government, although the question of greater import may be the legitimacy of the authority.

185. See generally FTC v. Sperry \& Hutchinson Co., 405 U.S. 233, 239-44 (1972); MagnusonMoss Warranty-Federal Trade Commission Improvennent Act, Pub. L. No. 93-637, 88 Stat. 2183 
cliange in focus from private to public imterests was addressed in 1976, when the Supreme Court decided Virginia State Board of Pharmacy $v$. Virginia Citizens Consumers Council, Inc. ${ }^{186}$ a case brought by "the public"-the potential recipients of the prohibited speecl.

The public interest proved determinative in Virginia Pharmacy. Indeed, the Court ignored the private interest of the speakers in communicating their commercial message. ${ }^{187}$ Justice Blackmun, writing for a nearly unanimous Court ${ }^{188}$ and using as his touchstone the interests of the potential recipients, eloquently appraised the value of maximizing the flow of information. Noting the keen public interest in the commercial information at issue, he asserted that its suppression affected most seriously those in the worst straits: the poor, the sick, and the elderly. ${ }^{189}$ Decrying the supposed advantages of a public kept in ignorance, Blackmun extolled the ability of the people to "perceive their own best interests if only they are well enough informed."190 Blackmun made clear that the public's interest is not simply the aggregate of the individual consuniers' interests; lie concluded that not only individual consuniers but

all of society may have a strong imterest in the free flow of commercial information. Even an individual advertisement, though entirely

(1975) (codified at 15 U.S.C. $\S \S 45-46,2301-2312$ (1976)). But see Federal Trade Commission Improvements Act of 1980, Pub. L. No. 96-252, §§ 5, 11, 19-21, 94 Stat. 374 (1980).

186. 425 U.S. 748 (1976). In Virginia Pharmacy a consumer group brought suit against the Virginia Pharmacy Board challenging the constitutionality of a statute that prohibited pharmacists from advertising prescription drug prices. Some of the groundwork for the Virginia Pharmacy holding was laid in New York Times Co. v. Sullivan, 376 U.S. 254 (1964). In the latter case, a defamation plaintiff argued that the advertisement in which he was hbeled should not raise first amendinent questions. Respondent's Brief at 30-31, New York Times Co. v. Sullivan, 376 U.S. 254 (1964). The plaintiff rehed on precedent in which the Court had seemingly created a commercial-speech exception to first amendinent protection. See Valentine v. Chrestensen, 316 U.S. 52, 54-55 (1942). But see Bigelow v. Virginia, 421 U.S. 809, 819-20 (1975); DeVore \& Nelson, Commerical Speech and Paid Access to the Press, 26 Hastings L.J. 745, 754 (1975). See also Metromedia, Inc. v. City of San Diego, $101 \mathrm{~S}$. Ct. 2882, $2891-92$ (1981) (opinion of White, J.). Moreover, the plaintiff pointed out that the imclnsion of editorial copy had not previously persuaded the Court to protect commercial speech and added that even the Times had classified the advertisement at issue as commercial. Respondent's Brief at 31, New York Times Co. v. Sullivan, 376 U.S. 254 (1964). Justice Brennan, writing for the Court, brushed aside the plaintiffs argument, however, noting that the advertisement at issue involved the civil rights movement. 376 U.S. at 266. It therefore raised issues "of the highest public interest." Id. Protection, accordingly, was granted. Breunan went on to sever the roots of seditious libel, but for present purposes it is significant that he crossed this initial hurdle by resort to the social-responsibility primciple of public interest.

187. The private interests in not communicating commercial messages were addressed, albeit perfunctorily. See 425 U.S. at 768-69.

188. Only Justice Rehnquist dissented. Justice Stevens took no part in the consideration or decision of the case.

189. 425 U.S. at 763.

190. Id. at 770 . 
"commercial," may be of general public interest. . . . Obviously, not all commercial messages contain the same or even a very great public interest element. There are few to which such an element, however, could not be added.191

It is illuminating to note that the "purely economic" nature of the advertisers' interests no longer disqualifies their speech from first amendment protection. ${ }^{192}$ The Court did not explain why the consumers' interests in the speech were keener than those of the advertisers, or why the advertisers' economic inotivations were apparently suspect, and yet the equally economic motives of consumers provided reasons for protecting the advertisers' speech. The reason can only be that libertarian principles were eschewed in favor of a social-responsibility analysis. Justice Blackmun dispelled any doubt regarding this conclusion by stating that although commercial speech is protected, "[s]oine forns of commercial speech regulation are surely permissible."193 Significantly, among the types of regulation to which commerical speech potentially is subject are prior restraint ${ }^{194}$ and compulsory expression ${ }^{195}$ - hallmarks of social-responsibility theory. ${ }^{196}$

Both prior restraint and compulsory expression have becoine tools of the FTC used to prohibit false or misleading advertising ${ }^{197}$ and to prohibit even commercial speech that inay well be true, but whose truth has not been proven to the Commission's satisfaction. ${ }^{198}$ The Commission regulates and fine tunes the content of the commercial speech that it approves by ordering affirmative disclosure ${ }^{199}$ and even corrective advertising ${ }^{200}$-all in the name of the public interest.

191. Id. at 764.

192. Id at 762. Under the Court's analysis the economic rights of the advertisers. are irrelevant.

193. Id at 770 .

194. Id. at $771-72 \&$ n.24.

195. Id. at 772 n.24.

196. See notes 133-36, 168 supra and accompanying text.

197. E.g., FTC v. Colgate-Palmolive Co., 380 U.S. 374 (1965) (use of mock-up to show that sandpaper could be softened with particular shaving cream); P. Lorillard Co. v. FTC, 186 F.2d 52 (4th Cir. 1950) (claim that one cigarette has less nicotine than other brands); De Forest's Training, Inc. v. FTC, 134 F.2d 819 (7th Cir. 1943) (representation by television repair school that unlimited opportunities would be present in growing industry).

An advertisement that may be literally correct, yet is open to misleading inference, is also subjcct to ceusure. See, e.g., Aronberg v. FTC, 132 F.2d 165 (7th Cir. 1942) (claim for "relief" from meustruation can be imterpreted as "cure"). See generally Developments in the Law-Deceptive Advertising, 80 HARv. L. REv. 1005, 1043-46 (1967).

198. See Pfizer, Inc., 81 F.T.C. 23, $62-64$ (1972).

199. See, eg., J.B. Williams Co. v. FTC, 381 F.2d 884 (6th Cir. 1967).

200. See, e.g., Warner-Lambert Co. v. FTC, 562 F.2d 749 (D.C. Cir. 1977), cert. denied, 435 U.S. 950 (1978); Beneficial Corp. v. FTC, 542 F.2d 611 (3d Cir. 1976), cert. denied, 430 U.S. 983 (1977). See generally Note, "Corrective Advertising" Orders of the Federal Trade Commission, 85 HARV. L. REV. 477 (1971). 
Although commercial-speech regulation represents the most pervasive implementation of the social-responsibility theory in first amendment jurisprudence, ${ }^{201}$ social-responsibility principles also predominate in obscenity law, ${ }^{202} \mathrm{im}$ the tort law of public disclosure of private facts, ${ }^{203}$ and particularly in the field of electronic-media regulation. ${ }^{204}$ The facial attractiveness of using the "public interest" as a justification for limiting the prerogatives of the imdividual makes further use of the theory in other areas of first amendment jurisprudence highly likely.

\section{A News-Gathering Right Considered}

After more than twenty-five years of discussion, 205 the United States Supreme Court recognized a first amendment news-gathering

201. This is not to say that an argument for the application of libertarian principles has not been made. See, e.g., D. Gillmor \& J. Barron, Mass Communications LAw 641 (3d ed. 1979); O. PEASE, supra note 177, at 150 (relating the argument as posed by advertisers of the 1920 s and 1930s).

202. See, e.g., Paris Adult Theatre I v. Slaton, 413 U.S. 49, 58-59 (1973); Miller v. California, 413 U.S. 15, 24 (1973).

203. See, e.g., Virgil v. Time, Inc., 527 F.2d 1122, 1129-30 (9th Cir. 1975), cert. denied, 425 U.S. 998 (1976); Restatement (Second) of ToRTs § 652(D), Comment h (1977). But cf. Bezanson, Public Disclosures as News: Injunctive Relief and Newsworthiness in Privacy Actions Involving the Press, 64 Iowa L. REv. 1061, 1073 (1979) (regulation by courts is limited in sense that "newsworthiness" or public interest should "invariably result from the fact of publication").

204. See note 169 supra and accoinpanying text. Cf. Community Communications Co. v. Boulder, 660 F.2d 1370, 1376-77, 1376 n.5 (10th Cir. 1981) (overturning preliminary injunction against city regulation of cable operations in interest of public).

205. Proposals for a constitutional news-gathering right date to at least 1952. See Note, Access to Official Information: A Neglected Constitutional Right, 27 IND. L.J. 209, 213 (1952). See generally Emerson, First Amendment Doctrine and the Burger Court, 68 CALIF. L. REv. 422, 464-65 (1980); Klein, Towards an Extension of the First Amendment: A Right of Acquisition, 20 U. MiAMI L. REv. 114, 146-47 (1965); Lee, Privacy Intrusions While Gathering News: An Accommodation of Competing Interests, 64 IowA L. REv. 1243, 1283 (1979); Lewis, supra note 29, at 798, 804-06; Note, The Right of the Press to Gather Information, 71 Colum. L. REv. 838, 839 (1971); Note, The Rights of Public and Press to Gather Information, 87 HARv. L. REv. 1505, 1506-10 (1974); Comment, Broadcasters' News-Gathering Rights Under the First Amendment: Garrett v. Estelle, 63 IowA L. REv. 724, 745 (1978); Comment, The Right of the Press to Gather Information After Branzburg and Pell, 124 U. PA. L. REv. 166, 166, 173 (1975). But see BeVier, supra note 43, at 493-94, 512-14; Gellhorn, The Right to Know: First Amendment Overbreadth?, 1976 WASH. U.L.Q. $25,25-28$.

See also Blasi, The Newsman's Privilege: An Empirical Study, 70 MiCH. L. Rev. 229, 265-74 (1971) (subpoenas interfere with reporting in various ways); Zimmerinan, supra note 89, at 644-47, 665 (needs of electronic media merit protection to facilitate news gathering); Note, Open Meeting Statutes: The Press Fights for the "Right to Know," 75 HARv. L. REv. 1199, 1203 (1962) (despite reasonable arguments for constitutional-access right, courts have not recognized it; thus statutory alternative is needed).

For a compreliensive review of the proposed bases for a reporter's right to withhold inforina* tion from disclosure-which are usually expressed in news-gathering rhetoric, see Comment, The 
right in Richmond Newspapers, Inc. v. Virginia ${ }^{206}$ In Richmond a Virginia trial judge granted the defendant's motion and excluded the pubhic and the press from a criminal trial, without making any evidentiary findings regarding prejudice or considering less drastic ineasures. ${ }^{207}$ The Supreme Court overturned on first amendment grounds the ruling of the trial judge. 208 The Chief Justice, also writing for Justices Stevens and White, rehed heavily on common law traditions, noting that "throughout its evolution, the trial has been open to all who care to observe." ${ }^{209}$ The Chief Justice found this unbroken tradition rooted in sound policy. Twice adverting to the "therapeutic value" of open justice, ${ }^{210}$ he recognized that public trials are essential to a "perception of fairness"211 and an "appearance of justice."212 These latter concerns obviate resort to self-help reinedies and assuage community sentiments of retribution. ${ }^{213}$ The interrelationship between history and policy gives rise to a constitutional presumption of openness that gains substance through the first amendment. 214 Because "explicit, guaranteed rights to speak and to publish concerning what takes place at a trial

Fallacy of Farber: Failure to Acknowledge the Constitutional Newsman's Privilege in Criminal Cases, 70 J. CRIM. L. \& CrImINology 299, 301-12 (1979). The argument for a reporter privilege to maintain confidentiality has been made since at least 1848. Id. 301-02. See also Blasi, supra, at 229 n.1 (quoting The Autobiography of Benjamin Frankin 69 (Yale Univ. Press 1964)).

206. 448 U.S. 555, 580 (1980). Chief Justice Burger noted that the nonenclature is unimportant, and it can just as easily be called a " 'right of access." " Id. at 576 (Burger, C.J.) (quoting Powell, J., in Gannett Co. v. DePasquale, 443 U.S. 368, 397 (1979)).

207. 448 U.S. at 560.

208. Only Justice Rehnquist dissented, mincing few words in remonstrating that his colleagues' interpretation of the Constitution threatened to undermine basic precepts of federalism. Id. at 605-06 (Rehnquist, J., dissenting). Justice Powell took no part in the decision.

209. Id. at 564 (Burger, C.J.); see id. at 565-69. Justice Brennan also emphasized the "legacy of open justice." Id. at 590 (Breunan, J., concurring in judgment). Justice Blackmun welcomed the Court's reliance "upon legal history in determining the fundamental public character of the criminal trial." Id. at 601 (Blackmun, J., concurring in judgment). See also Gannett Co. v. DePasquale, 443 U.S. 368, 419-33 (1979) (Blackmun, J., dissenting in part).

210. 448 U.S. at $569-70$ (Burger, C.J.).

211. Id. at 570 .

212. Id. at 572 (quoting Offutt v. United States, 348 U.S. 11, 14 (1954)). Justice Stevens has noted that the "mere existence of inflexible access barriers generates a concern that conditions within the closed institution require especially close scrutiny." Houchins v. KQED, Inc., 438 U.S. 1, 22 n.7 (1978) (Stevens, J., dissenting).

213. 448 U.S. at $570-73$.

214. Id. at 575. "From this unbroken, uncontradicted history, supported by reasons as valid today as in centuries past, we are bound to conclude that a presumption of openness inheres in the very nature of a criminal trial under our system of justice." Id. at 573. Burger referred to this presumption numerous times. See $i d$. at 567, 569, 575-77, 580 n.17. "In guaranteeing freedons such as those of speech and press, the First Amendment can be read as protecting the right of everyone to attend trials so as to give meaning to those explicit guarantees." Id. at 575. "The right of access to places traditionally open to the public, as criminal trials have long been, nuay be seen as assured by the amalgam of the First Amendment guarantees of speech and press . . . ." Id. at 577 . 
would lose much meaning" if arbitrarily denied,215 "the right to attend criminal trials is implicit in the guarantees of the First Amendment."216

The question that presents itself in the wake of this "watershed case"217 is the scope of the news-gathering right beyond the criminaltrial context. ${ }^{218}$ The traditions and policies ${ }^{219}$ that produce a presump-

215. Id at 576-77 (emphasis added).

216. Id. at 580 (emphasis added). Justice Stewart, author of the majority opinion in the pretrial courtroom-closure case, Gannett Co. v. DePasquale, 443 U.S. 368 (1979), concurred in the judgment in Richmond and wrote separately to point out that in Gannett the first amendment issue has been squarely addressed only by Justice Powell, who stated that the first amendment gives "at least a limited right of access." 448 U.S. at 599 (Stewart, J., concurring in judgment). Justice Blackmun concurred in the judgment as well, writing separately to note that he supported the resnlt on first amendment grounds only as a secondary position. Id. at 604 (Blackmun, J., concurring in judgment). He believed that his dissenting opinion on sixth amendment grounds in Gannett had been vindicated to the extent that the Court was now more receptive to his historical interpretation of the public nature of trails, and that the confusion over the inferenees to trails as well as to pre-trial hearings in Gannett had been clarified. Id at 601-02.

Justice Brennan, jomed by Justice Marshall, concurred in the judgment and availed himself of the opportunity to explicate his structural model of the first amendment. See id. at 587 (Brennan, J., concurring in judgment). "The structural model links the First Amendment to that proeess of communication necessary for a democracy to survive, and thus eutails solicitude not only for communication itself, but for the indispensable conditions of meaningfnl communication." Id. at 587-88. Thus, a valid first amendment claim can be made whenever the citizens' need for information relevant to self-government is at issue. See id. at 585-89. Brennan recognized the exceedingly broad dimensions of the first amendment's coverage under this analysis. Id. at 588 . He noted that "almost insurinonntable" protection was accorded outright communication between speakers and listeners. Id. at 587. When the antecedents to the actual communication were at issue, rather than the communication itself, he proposed two principles to focus analysis: the "tradition of public entry to particular proceedings or infornation" and whether access promotes objectives of the particular government process. Id. at 589. In slort, the interests in obtaining the information must be balanced against the opposing interests invaded. See id. Brennan conducted a lengthy examination of the "essentially unwavering rule" regarding public trials under English and Umited States common law and the United States Constitution. Id. at 589-93. He noted that "the conduct of a trial is preeminently a matter of public interest," id. at 596, and concluded that "[p]opnlar attendance at trials . . . substantially furthers the particular public purposes of that critical judicial proceeding." Id. at 597 . Because tradition and public imterests militated strongly against closure, Brennan concurred that the first amendment required that the trial be public. Id. at 598 .

217. $I d$. at 582 (Stevens, J., concurring).

218. The right most likely extends to civil trials as well. See $i d$. at $580 \mathrm{n.17}$ (Burger, C.J.); id at 598-601 (Stewart, J., concurring in judgment). Judge Prentice Marshall of the District Court for the Northern District of Illinois has suggested that the right covers not only attendance at trials, but also inspection of court records. Address by Judge Marshall, University of Illinois Department of Journalism (Feb. 20, 1981); see United States v. Carpentier, 526 F. Supp. 292, 294-95 (E.D.N.Y. 1981); Litton Systems, Inc. v. AT\&T, 7 Media L. Rep. (BNA) 1903, 1903 (S.D.N.Y. Sept. 2, 1981); People v. Peterson, No. 81-CF-397, slip op. at 1 (Cir. Ct., Clrampaign County, Ill,, Apr. 23, 1981) (public lias first amendinent riglt to examine court file); $c f$. In re NBC, 635 F.2d 945, 951-52 (2d Cir. 1980) (common law right of inspection furthers interests articulated in Richmond). Anthony Lewis has suggested an expansive interpretation. See Lewis, $A$ Right to be Informed, N.Y. Tines, Jnly 3, 1980, at A19. Of course, the holding can be limited to its facts, and the first amendment interests may be subordinated even in criminal trials when an "overriding interest [is] articulated in the findings." 448 U.S. at 581 (Burger, C.J.). 
tion of openness at a trial may be equally persuasive in other settings. Just as a trial can be considered a public forum in which the right to hear is as important as the right to speak, ${ }^{220}$ so too can the public nature of other forums within government control provide grounds for a guarantee of unrestricted access under the Richmond rationale. ${ }^{221}$ Moreover, even when arguments of tradition and policy are not as compelling, the interests justifying denial of access may also be less forceful. ${ }^{222}$ In this respect, the cases preceding Richmond offer inore insight into the probable scope of a news-gathering right than does Richmond itself. We first examine the analytical foundations of a news-gathering right in terins of social-responsibility and libertarian principles. Then an alternative analytical framework is proposed which accommodates a libertarian imterpretation of private speech and press rights and fulfills the public right to information within government control.

\section{A. Development of a News-Gathering Right.}

The Supreme Court has made two choices that dominate the analysis of the news-gathering right. First, the Court has defined the rights of the press by reference to the rights of the public.223 Second, the Court has concentrated its prior-restramt analysis on the use 224 or availability 225 of a medium. Declining to employ prior-restramt nomenclature when addressing questions of obtaming information, ${ }^{226}$ the Court lias distinguished the gathering of information from its publica-

219. Recognition of custom along with its underlying policy can be imterpreted as giving constitutional dimension to common law access rights. See, e.g., In re NBC, 635 F.2d 945, 949-52 (2d Cir. 1980) (ABSCAM tapes case, citing Richmond as consistent with common-law right of access to judicial records).

220. See note 156 supra. See Brief for Amici Curiae in Support of Jurisdictional Statement, The Reporters Committee for Freedom of the Press, at 21, 26, Richmond Newspapers, Inc. v. Virginia, 448 U.S. 555 (1980).

221. See Hague v. CIO, 307 U.S. 496, 515 (1939) (opinion of Roberts, J.) (the traditional openness of streets and parks); Kalven, supra note 156, at 13-15, 32. See also Cass, supra note 20, at 1287, 1318-37 (indicating various policy reasons central to the analysis of public forum cases).

222. See, e.g., Houchins v. KQED, Inc., 438 U.S. 1, 36-38 (1978) (Stevens, J., dissenting); Saxbe v. Washington Post Co., 417 U.S. 843, 864-70 (1974) (Powell, J., dissenting).

223. See notes 231-34 infra and accompanying text.

224. See, e.g., Nebraska Press Ass'n v. Stuart, 427 U.S. 539, 558 (1976); Bantam Books, Inc. v. Sullivan, 372 U.S. 58, 70 (1963); Near v. Minnesota ex rel. Olson, 283 U.S. 697 (1931).

225. See, e.g., Southeastern Promotions, Ltd. v. Conrad, 420 U.S. 546 (1975); Sliuttlesworth v. Birmingham, 394 U.S. 147 (1969); Schneider v. State, 308 U.S. 147 (1939); Lovell v. Griffin, 303 U.S. 444 (1938).

226. See Gannett Co. v. DePasquale, 443 U.S. 368, 393 n.25 (1979); id. at 399 (Powell, J., concurring). 
tion. Presumably, gathering is considered sufficiently prior to publication to be subject to restraint.

The press first urged the Court to fashion protection for news gathering in Branzburg v. Hayes. ${ }^{227}$ To require a reporter to testify before a grand jury, it was argued, would deter potential news sources froin disclosing information to the press, thereby inhibiting the flow of infornation to the public. ${ }^{228}$ Branzburg typifies the situation in which news gathering is at issue only indirectly. ${ }^{229}$ The Court declared the potential deleterious effects on news gathering to be "speculative" and held that reporters must testify regardless of the "incidental burdening" that may result.230 The Branzburg rationale is summarized in the Court's repeated assertion that the right of the press is no greater than that of the public. ${ }^{231}$ For example, Branzburg author Justice White repeatedly addressed the duty of all citizens to testify before a grand jury. ${ }^{232} \mathrm{He}$ appeared to question not only whether the proposed burden on the first amendment interests of reporters was sufficiently certain, but also whether it was inordinately distinct froin the burden imposed on anyone compelled to testify. ${ }^{233}$ White stated his rationale in the form of a conclusion that was quoted and relied on heavily by the authors of the subsequent prison-access cases: "It has generally been held that the First Amendment does not guarantee the press a constitutional right of special access to information not available to the public generally. . . . Newsinen have no constitutional right of access to the scenes of crime or disaster when the general public is excluded . . .."234

Analysis of the private-press right of nondisclosure in terms of a correlative public right is perhaps understandable given the "long-

227. 408 U.S. 665 (1972).

228. Id. at $679-80$.

229. See, e.g., Zurcher v. Stanford Daily, 436 U.S. 547 (1978) (primarily a fourth amendment case in which the issue concerned the constitutionality of issuing a search warrant for mere evidence against a nonsuspect third party); Reporters Comm. for Freedom of the Press v. AT\&T, 593 F.2d 1030 (D.C. Cir. 1978), cert. denied, 440 U.S. 949 (1979) (subpoenas for journalists' toll-call records).

230. 408 U.S. at 682,694 ; see id. at $690-95$.

231. See, e.g., Houchins v. KQED, Inc., 438 U.S. 1, 9, 11 (1978) (Burger, C.J.); Saxbe v. Washington Post Co., 417 U.S. 843, 850 (1974); Pell v. Procunier, 417 U.S. 817, 834-35 (1974); Branzburg v. Hayes, 408 U.S. 665, 684-85 (1972).

232. See 408 U.S. at $682,685-86,688,690-91,697,702$.

233. See id. at 686-92.

234. Id. at 684-85, quoted in Houchins v. KQED, Ine., 438 U.S. 1, 11 (1978) (Burger, C.J.); see Pell v. Procunier, 417 U.S. 817, 833-34 (1974). The authors of Branzburg and the prison-access cases also found persuasive Chief Justice Warren's observation in Zemel v. Rusk, 381 U.S. 1 (1965) that the "right to speak and publish does not carry with it the unrestrained right to gather information." Id. at 17, quoted in Houchins v. KQED, Inc., 438 U.S. 1, 12 (1978) (Burger, C.J.); see Pcll v. Procunier, 417 U.S. 817, 834 n.9 (1974); 408 U.S. at 684. 
standing principle that 'the public . . . has a right to every inan's evidence." "235 But deciding the question of the press's news-gathering right in terms of the public's right leaves the question begging an answer; ${ }^{236}$ one unknown is defined in tenns of another. ${ }^{237}$ More significantly, by diverting analysis from the right of the party before the Court to the right of the public, one takes a long step toward implementation of social-responsibility principles.

The first justification for resort to the "no greater than" approach seems to involve the fear of bestowing extraordinary first amendment privileges on the press as an imstitution. One must define the "press" in order to determine who it is that merits this greater or different right. ${ }^{238}$ The Court alluded to this concern in Branzburg when Justice White wrote that the guarantee of press freedom is conferred not only on the metropolitan pubhisher, but also on the "lonely pamphleteer who uses carbon paper or a mimeograph."239 Perhaps the private interest of any speaker or publisher is sufficient to mandate recognition of a newsgathering right. The Court avoided this much more explosive question and at the same time created justifications for the result it chose by asking the question in terms of a public right.

The second problem ancillary to the Court's recognition of a newsgathering right is unavoidable regardless of whether the right is defined in public or private terms. When denying recognition of a press right, the Court has alluded to the impracticality of the opposite result. ${ }^{240}$

235. 408 U.S. at 688 (quoting 8 J. WIGMORE, EvideNCE § 2192 (J. McNaughton rev. ed. 1961). Courts inevitably make no reference to a subsequent passage in which Wigmore admonishes society to "make the duty as little onerous as possible." Id. (emphasis in original). The duty to appear before a grand jury as a consequence of performing a constitutionally protected function takes on the character of subsequent punishment, making the duty rather onerous indeed. See BeVier, supra note 43 , at 495 n.59.

236. See Lee, supra note 205, at 1250-53. As Judge Hufstedler noted in KQED, Inc. v. Houchins, 546 F.2d 284 (9th Cir. 1976), rev'd, 438 US. 1 (1978), the statement that the right of the press is coextensive with the public's right is not "helpful in absence of any description of what the public's right is or how the right is to be vindicated." 'Id. at 295 (Hufstedler, J., concurring).

237. Note, The Rights of Public and Press 10 Gather Information, 87 HARv. L. REv. 1505, 1507 (1974).

238. Compare First Nat'l Bank v. Bellotti, 435 U.S. 765, 801 (1978) (Burger, C.J., concurring) with Bezanson, supra note 1, at 781-85.

239. 408 U.S. at 704. Branzburg notwithstanding, the Court has never directly addressed the necessity, in constitutional terms or otherwise, of distinguishing between press and public. First Nat'l Bank v. Bellotti, 435 U.S. 765, 798 (1978) (Burger, C.J., concurring); see State ex rel. Dayton Newspapers, Inc. v. Phillips, 46 Ohio St. 2d 457, 501, 351 N.E.2d 127, 153 (1976) (Celebrezze, J., dissenting); cf. Hutchinson v. Proxmire, 443 U.S. 111, 133 n.16 (1979) (application of New York Times standard in libel suits to private-individual defendants rather than to inedia defendants has never been decided by the Court). See generally Blanchard, supra note 1, at 232-34.

240. See Houchins v. KQED, Inc., 438 U.S. 1, 12-14 (1978) (Burger, C.J.); Saxbe v. Washington Post Co., 417 U.S. 843, 871 (1974) (Powell, J., dissenting); 408 U.S. at 702-04 \& n.39. 
The Court has indicated that it is unwilling to become mvolved in caseby-case analyses of the scope of the right. ${ }^{241}$ The broad command of the first ainendment affords the courts no guidelines in access cases. ${ }^{242}$ The Court's assumption is that the legislature or the executive is the better body to inake and implement such decisions. ${ }^{243}$ Absent statutory authority, the Court is reluctant to fashion ad hoc standards.244

We can look with some syinpathy on the Court's desire to avoid the intractable questions that the recognition of a private news-gathering right would entail. By distinguishing news gathering from news publishing the Court has been and will continue to be able to avoid the questions attached to both the public and private rights. Moreover, it is unlikely to confront the issue until convimced of the necessity of such a right. In Branzburg, for exainple, the Court questioned whether any potential burden on news gathering is of sucli a magnitude to merit a press privilege not to testify. The Court was skeptical that all confidential sources would "dry up." In Pell v. Procunier 245 and Saxbe v. Washington Post Co. ${ }^{246}$ the first prison-access cases, the Court disagreed with the press's contention that face-to-face interviews witl specifically designated inmates is an appreciably superior and more effective method of gathering news. The Court detailed alternative ineans of communication with inmates, including inailed correspondence, random interviews while touring, and contacts with inmates recently released. ${ }^{247}$ Likewise, in the inost recent prison-access case, Houchins $v$. $K Q E D$, Inc. ${ }^{248}$ the denial to the press of physical access was justified

241. See Houchins v. KQED, Inc., 438 U.S. 1, 14 (1978) (Burger, C.J.); 408 U.S. at 702 n.39. But see 438 U.S. at 18 (Stewart, J., concurring).

242. See BeVier, supra note 43, at 506-12.

243. See 438 U.S. at 12 (Burger, C.J.); id. at 34-35 (Stevens, J., dissenting); BeVier, supra note 43 , at $513-14$.

244. See generally Ely, Constitutional Interpretivism: Its Allure and Impossibility, 53 IND. L.J. 399 (1978).

The central dispute in constitutional theory has gone under different namcs at different times, but today's terminology seems as helpful as any. Today we are likely to call the contending sides "interpretivism" and "noninterpretivism"-the former indicating that judges deciding constitutional isstes should confine themselves to enforcing values or norms that are stated or very clearly implicit in the written Constitution, the latter indicating the contrary view that courts should go beyond that set of references and enforce values or norms that cannot be discovered within the four corners of the document. . . . What distinguishes interpretivism from its opposite is its insistence that the work of the pohtical branches is to be invalidated only in accord with an inference whose starting point, whose underlying premise, is fairly discoverable in the Constitution.

Id. at $399-400$.

245. 417 U.S. 817 (1974).

246. 417 U.S. 843 (1974).

247. Saxbe v. Washington Post Co., 417 U.S. at 847-48; Pell v. Procunier, 417 U.S. at 830.

248. 438 U.S. 1 (1978). 
by the proposition that the press can learn of jail conditions in various other ways, "albeit not as conveniently as [it] might prefer."249

Rehance on alternative neans of exercisnig rights does not con1port with standard libertarian interpretation, ${ }^{250}$ which first questions the justification for state infringement on individual liberties ${ }^{251}$ and then focuses on the availability of alternative means for the state to accomplish its ends without impinging private interests. ${ }^{252}$ The burden, in a hbertarian analysis, clearly is on the state to denionstrate why private interests cannot be accommodated. If the state cannot ineet this burden, it must defer to the individual's choice of forum ${ }^{253}$ and content, ${ }^{254}$ even if the individual is asserting a news-gatlering right. ${ }^{255}$ But the burden seems to be on the individual in the news-gatlering cases; the person seeking access must overconie a presuniption favoring the government's determination of the public right of access and of the means by which that right is best served. By orienting the analysis in terms of the public right rather than the private right, the Court has eschewed resort to a body of law founded on libertarian principles and has given itself great latitude to substitute the judgnient of the state for that of the imdividual in deciding the extent to which rights exist. The

249. Id at 15.

250. See Southeastern Promotions, Ltd. v. Conrad, 420 U.S. 546, 556 (1975); Schneider v. State, 308 U.S. 147, 163 (1939); cf. Branzburg v. Hayes, 408 U.S. 665, 733-36 (1972) (Stewart, J., dissenting) (amount of deference to be accorded first amendment rights is demonstrated by repeated holdings of unconstitutionality im cases in which the restriction is rationally" related to the exercise of the right). But see Garcia v. Gray, 507 F.2d 539, 543 (10th Cir. 1974), cert. denied, 421 U.S. 971 (1975); Council of Greenburgh Civic Ass'ns v. United States Postal Serv., 448 F. Supp. 159, 163 (S.D.N.Y.), rev'd, 586 F.2d 935 (2d Cir. 1978), on remand, 490 F. Supp. 157 (S.D.N.Y. 1980), rev'd, 101 S. Ct. 2676 (1981).

251. Schad v. Borough of Mount Ephraim, 101 S. Ct. 2176, 2183 (1981) (quoting Schneider v. State, 308 U.S. 147, 161 (1939)); Tinker v. Des Momes Indep. Community School Dist., 393 U.S. 503, 508-11 (1969); Bates v. City of Little Rock, 361 U.S. 516, 524 (1960). See note 82 supra.

252. Schad v. Borough of Mount Ephraim, 101 S. Ct. 2176, 2183-84 (1981) (quoting Village of Schaumburg v. Citizens for a Better Environment, 444 U.S. 620, 637 (1980)); Nebraska Press Ass'n v. Stuart, 427 U.S. 539, 563-64 (1976). Inquiry into the availability of alternative means of communication is undertaken if the regulation concerns the time, place, or manner of expression and only if the government carries its burden regarding the first two imquiries. See Grayned v. City of Rockford, 408 U.S. 104, 119-21 (1972); Kovacs v. Cooper, 336 U.S. 77, 81-82, 87-89 (1949); cf. Limmark Assocs. v. Township of Willingboro, 431 U.S. 85, 93-94, 97 (1977) (consideration of nonexistence of alternative methods of communication as well as identification of asserted state interest in regulation and of alternative means of furthering that interest in a commercial-speech case).

253. See Southeastern Promotions, Ltd. v. Conrad, 420 U.S. 546, 556 (1975); Schneider v. State, 308 U.S. 147, 163 (1939).

254. See National Socialist Party v. Village of Skokie, 432 U.S. 43, 43-44 (1977); Cohen v. California, 403 U.S. 15, 24-26 (1971); Organization for a Better Austin v. Keefe, 402 U.S. 415, 418 (1971). See note 82 supra.

255. The breadth of such a news-gathering right and the problems associated with such an interpretation, both of which may explain why the Court is seeking an alternative approach, are discussed at notes 305-06 infra and accompanying text. 
court reconciled this adoption of a social-responsibility framework for interpreting a news-gathering right with the usual libertarian analysis by distinguishing between prior restraint of gathering and prior restraint of publication. Notwithstanding that the news-gathering efforts of the press inay be impinged to some degree in each case, the Court has thought it significant that the press remains free to publish whatever inforination it can acquire. Thus, the Court has constructed a dichotony between gathering and publication, the viability of which is crucial to the principled application of disparate theories to the newsdissemination process.

Before Gannett Co. v. DePasquale, ${ }^{256}$ therefore, the Court maintained that news gathering is a distinct component of news dissemination, and it based its consistent refusal to recognize a first anendinent right to gather news on three premises: press rights are concomitant with public rights; the lack of concrete standards to guide judicial implementation of a news-gathering right requires deference to other branches; and the news-gathering method preferred by the press may be unnecessary in light of alternatives. Of these, only the third was relevant in Gannett.

In Gannett a reporter had been denied access to a pretrial suppression hearing. The attorney for the two inurder defendants had made the notion to close the hearing and neither the prosecutor nor the reporter present had objected. The following day, however, the reporter requested that she be allowed to cover the hearing and that she be given access to the transcript. The trial judge concluded that opening the suppression hearing would create a "reasonable probability of prejudice" to the defendants, and refused to reopen the hearing. ${ }^{257} \mathrm{He}$ declined to release the transcript immediately. The United States Supreme Court upheld the decision of the New York Court of Appeals 258 that the trial judge's ruling was correct.

The press sought no special privilege in Gannett. The right of access under the first anendment was posited as belonging to the public as well as the press. There was, therefore, no problem of defining press. Furthermore, there was no other branch to which the Court could defer for a more principled resolution; no other branch would be better able to fashion and implement a right of access. In short, the question was presented to the body best equipped to address and resolve the issue.

256. 443 U.S. 368 (1979).

257. Gannett Co. v. DePasquale, 55 App. Div. 107, 110 (1976), rev'd, 43 N.Y.2d 370, 401 N.Y.S.2d 756, 372 N.E.2d 544 (1977), affd, 443 U.S. 368 (1979).

258. 43 N.Y.2d 370, 401 N.Y.S.2d 756, 372 N.E.2d 544 (1977), affd, 443 U.S. 368 (1979). 
The only remaining justification for rejecting a first amendinent right of access was a holding that the information need not be made available in the manner preferred by the press-attendance at the hearing. Justice Stewart, writing for the majority, stated that the Court need not reach the question whether there is a first amendment right of access because the trial judge had assumed the existence of such a right and had given it appropriate consideration. ${ }^{259}$ It is significant, though, that the intermediate New York court had reversed the judgment of the lower court because the trial judge had demonstrated no deference to a constitutional imtcrest in access. ${ }^{260}$

Stewart pointed out im a footnote that there had been no attempt to prevent publication of information in the possession of the press. ${ }^{261} \mathrm{He}$ thus limited the question to demal of access and distinguished prior restraint of publication. The Court's unanimous disaffection with "gagging" the press evinced in Nebraska Press Association v. Stuart ${ }^{262}$ was, therefore, of no assistance to the press in Gannett. In the pretrial context, the Court apphed a less stringent standard of justification for restraint of a first amendment news-gathering right. Instead of requiring a showing of grave and imminent danger to the fair administration of justice, the court required, at inost, a showing of a reasonable probability of prejudice. ${ }^{263}$ Furthermore, in Nebraska Press the Court focused on the restraint and forced the state to prove the absence of less restrictive alternatives, but in Gannett the Court focused on the news gathermg and forced the press to establish the absence of alternative news-gathering inethods. A transcript of the suppression hearing had been made available to the press once the potential for prejudice had been eliminated. Thus, there was a "full opportunity" to inform the public $^{264}$ and little reason to accommodate the preferences of the press.

259. 443 U.S. at 392.

260. The appellate court noted that the only finding the trial judge had made before concluding that there was a "reasonable probability of prejudice" was that one of the defendants was a juvenile. Gannett Co. v. DePasquale, 55 App. Div. 107, 110 (1976), rev'd, 43 N.Y.2d 370, 401 N.Y.S.2d 756, 372 N.E.2d 544 (1977), affd, 443 U.S. 368 (1979). Nonetheless, Justice. Stewart adopted the trial judge's approach and conclusion.

261. 443 U.S. at 393 n.25.

262. 427 U.S. 539 (1976).

263. See 443 U.S. at 393. The effect, if any, that the Richmond holding will have in revising this standard is uncertain. See Richmond Newspapers, Inc. v. Virginia, 448 U.S. 555, 598 (1980) (Stewart, J., concurring). Indeed, the Richmond standard even as applied to trials is unclear. See 1 PRactising Law Institute, Communications Law 1980, at 392-98 (1980).

264. 443 U.S. at 393. But see note 269 infra. 


\section{B. Implications of the Gathering/Publication Dichotomy.}

It can be said that there was an assumption in the news-gathering cases as significant as any assumption yet articulated: that the magnitude of the competing societal interests in every case ${ }^{265}$-and most markedly in Gannett-justified nonrecognition of a news-gathering right. Although conceding the existence of countervailing interests, the Court arguably has improperly conducted its balancing by failing to account for societal interests favoring the press's preferred method of news gathering.

But a more careful analysis of the Court's approach reveals its true critical flaw. The Court lacks a cogent philosophy concerning news gathering and, therefore, tends to analyze news-gathering cases with its focus on publication. The Court's justifications for allowing impingement on news gathering are irrelevant to the actual news gathering at issue and in fact stem from the perceived negative effects of allowing pubhication. For example, the fear in the prison-access cases was that media coverage would give undue prominence to particular inmates, making them "big wheels," and creatimg disciplinary problems. ${ }^{266} \mathrm{Al}-$ though the Court has claimed it is distimgnishing between gathering and dissemination, ${ }^{267}$ its foremost concern is with publication. The Court's claimed distimction between gathering and publication allows it to permit prior restramts-in the traditional sense-on news dissenimation. Particularly in Gannett, the Court's concern was with a "reasonable probability of prejudice" that only publication could have engendered. ${ }^{268}$ No governunental interest was ever asserted as a justification for limiting news gathering. Indeed, it is questionable whether any governmental interest exists that justifies restrictions on the inere gathering of news.

265. See Saxbe v. Washington Post Co., 417 U.S. 843, 866-68 \& n.10 (1974) (Powell, J., dissenting). But see Richınond Newspapers, Inc. v. Virginia, 448 U.S. 555, 583 (1980) (Stevens, J., concurring) (absence of legitimate interests opposed to access in $K Q E D$ ); Lee, supra note 205, at $1250-51$.

266. Saxbe v. Washington Post Co., 417 U.S. 843, 866-68 \& n.10 (1974) (Powell, J., dissenting).

267. As Professor Bezanson observed, the act of publication

is inseparable from the means of obtaining the information in the first instance. To conclude, as do many of the Supreme Court's prior restraint cases, that once obtained any information may be published, but that the custodian inay be controllcd so as to prevent disclosure, is to rest the system of legal protection not only on imperfectly logical but also on impractical, unrealistic, and unresponsive assumptions. In the end, the saine issues must be faced, the saine analytical framework must be applied, and the sane balanced judgment must be reached....

Bezanson, supra note 203, at 1109 (footnote omitted). See Allen v. Coinbined Commumications Corp., 7 Media L. Rep. (BNA) 2417, 2419 (Colo. Dist. Ct. July 22, 1981). See also Goodale, supra note 160 , at 34; Lewis, supra note 29 , at 802.

268. Gannett Co. v. De Pasquale, 443 U.S. 368, 376 (1979). 
A hypothetical situation further demonstrates the flaw in the Court's analysis. To obtain access to the pretrial hearing, the Gannett reporter need only have promised not to publish information gatliered at the hearing until the information was no longer prejudicial. ${ }^{269}$ If the reporter had agreed not to report on the proceedings until, for example, jurors were empaneled and sequestered, then the jurors would not have been exposed to any evidence ruled imadmissible at the pretrial hearing. They would have retamed whatever impartiality they had possessed, not because the reporter had not gathered the news but because she had not published the news. Thus, the defendant's rights are not affected, but the reporter's "right" is subject to judicial oversight. Accurately defining the fear of the trial judge reveals that the supposed diclotomy between gathering and publication is a pretext for precluding or conditioning publication.

The power to establish conditions ${ }^{270}$ and limitations on access is tantamount to the power to dictate the content of the news. The "news" that government officials reveal is the news that the reporters

269. See generally FED. R. CRIM. P. 43.1(c) (Preliminary Draft of Proposed Amendments 1981) (allowing court to impose limitations on access and disclosure).

Given the choice, any reporter would prefer to witness a hearing and write a story for delayed publication rather than struggle through a transcript long after the fact. Not ouly is reading a transcript tedious, but it is impossible to glean from the transcript the nuances of speech, the ineptitude of attorneys and judges, or the "deal" that was consummated but stricken from the record. See Richmond Newspapers, Inc. v. Virginia, 448 U.S. 555, 597 n.22 (1980) (Brennan, J., concurring); Oxnard Publishing Co. v. Superior Court, 68 Cal. Rptr. 83, 95-96 (Cal. App. 1968) (vacated as inoot after change of venue granted). Indeed, reporters who take their duties seriously may consider it incumbent on themselves to obtain access to such proceedings despite the price.

The trial court in Federated Publications v. Swedberg, 633 P.2d 74 (1981), took an approach similar to the one hypothesized in the text. The judge imposed as a condition to media attendance at a pretrial hearing the signing of an agreement to abide by bench-bar-press guidelines. The Washington Supreme Court upheld this device, noting that the court order "did not involve a prior restraint upon the exercise of free speech." Id. at 77. Elsewhere the court said, "Inasmuch as the court had the authority ... to exclude all of the public, it had also the included power to impose reasonable conditions upon attendance." $I d$. at 78 . The transparent intent of the court, however, was to impose conditions on publication, not attendance.

270. See Wiseman v. Massachusetts, 398 U.S. 960, 963 (1969) (Harlan, J., dissenting from denial of certiorari); Commonwealth v. Wiseman, 356 Mass. 251, 253-54, 249 N.E.2d 610, 612-13, cert. denied, 398 U.S. 960 (1969); Federated Pubhications v. Swedberg, 633 P.2d 74, 78 (1981); Cohen, Reconciling Media Access with Confidentiality for the Individual in Juvenile Court, 20 SANTA Clara L. Rev. 405, $421-23$ (1980); Zimmerman, supra note 89, at 701-03; Note, Access to Official Information: A Neglected Constitutional Right, 27 IND. L.J. 209, 209-10 (1952). See also CBS v. FCC, 101 S. Ct. 2813, 2829 (1981); Snepp v. United States, 444 U.S. 507, 511 (1980). "A hicensed broadcaster is 'granted the free and exclusive use of a limited and valuable part of the public domain; when he accepts that franchise it is burdened by enforceable obligations." " $101 \mathrm{~S}$. Ct. at 2829 (quoting United Church of Christ v. FCC, 359 F.2d 994, 1003 (D.C. Cir. 1966)).

Parallels can be drawn to the doctrine of unconstitutional conditions, which limits the conditions government may place on the exercise of a privilege. See, L. Tribe, American ConstituTIONAL LAW 510 \& n.30, 710 n.57 (1978). 
report.271 Of course, "the Press is free to try to uncover, and if it succeeds it is free to publish"272 the information that the government attempts to conceal. But, as the same commentator noted, the success of the press in uncovering information from the government is "rare, haphazard [and] fortuitous."273 Numerous "public information specialists"274 throughout the government who manage, and arguably filter, information determine the information that the press and public receive. ${ }^{275}$ The facts that such publicists prefer not to be published are, of course, likely to be withheld. By controlling news gathermg the government can effectively both proscribe and prescribe news dissemina-

271. See T. Crouse, The Boys on the Bus 209 (1972) (during the Nixon years the White House became a "massive public relations operation, exercising more and more control over the distribution of the news"); C. Peters, How Washington Really Works 22 (1980) (quoting Carter administration speechwriter James Fallows):

Within the White House, weekly summaries of the President's schedule were prepared; for each day, they listed what the likely "news event" would be. Under normal circumstances, that prediction almost always came true; if the President was making an announcement about the U.S. Forest Service, the Forest Service would get one day's news-and would not be in the news again until another announceinent was planned.

Professor Van Alstyne has noted that influential and newsworthy public officials need "simply rely on the public-spiritedness and competitive avarice of the private press to reach the public. It does not involve governmentally owned presses or broadcast facilities dedicated to the espousal of an official line, but it simply counts upon the regular press for its ready dissemination." Van Alstyne, The First Amendment and the Suppression of Warmongering Propaganda in the United States: Comments and Footnotes, 31 LAW \& CoNTEMP. ProBs. 530, 535-36 (1966).

272. Henkin, The Right to Know and the Duty to Withhold: The Case of the Pentagon Papers, 120 U. PA. L. REV. 27I, 278 (1971).

273. Id.

274. The Civil Service terms for public-relations positions include "public information specialist" and "public information officer." D. WISE, supra note 83, at 206. The euphemism is necessitated in part by a stautory restriction on publicity experts. Id. at 206-07; see 5 U.S.C. $\S 3107$ (1976).

275. See 123 Cong. Rec. 24,848-51 (1977) (remarks of Sen. Scott); C. Peters, How WashINGTON REALly Works 18 (1980); C. STEINIBERG, THE INFORMATION EsTablishMENT-OUR GOVERNMENT AND THE MEDIA 4, 53-54, 91 (1980); D. WISE, supra note 83, at 206-07, 209-10; Lewis, supra note 29, at 797. See also W. LIPpMan, Public OpINION 217-18 (1965):

The enormous discretion as to what facts and what impressions shall be reported is steadily convincing every organized group of people that whether it wishes to secure publicity or to avoid it, the exercise of discretion cannot be left to the reporter. It is safer to hire a press agent who stands between the group and the newspapers. Having hired him, the temptation to exploit his strategic position is very great. . .

... [T] he picture which the publicity inan makes for the reporter is the one he wishes the public to see. He is censor and propagandist, responsible ouly to his employers, and to the whole truth responsible ouly as it accords with the employer's conception of his own interests.

The danger of providing selective access to information, as Hocking observed, "is the ease of falsifying without lying, as by the omission of relevant facts. There is no more effective type of lie than a skilfully biased selection of truth." W. HockING, supra note 23, at 115-16. Another commentator noted, "It is a truism that, if a governing structure based upon widespread genuine citizen opmions is to survive as a viable democracy, it must place legal restraints on the government's ability to mamipulate the formulation and expression of that opinion." Ziegler, Government Speech and the Constitution: The Limits of Official Partisanship, 21 B.C.L. REv. 578, 580 (1980). 
tion. Because news gathering by the press is a continuous process, government officials can use access privileges as a lever to influence the manner of presentation of facts that have been obtained. Pressures can be exerted on those desirous of continuing access to be "objective"276 or even biased in favor of government. 277

Any role for government either in limiting or in ordaining the content of a publication is antithetical to libertarian precepts. ${ }^{278}$ Government's role in regulating the gathering of inforination can be justified under social-responsibility theory, 279 however, because government is presumed to act in the public imterest and is the ultimate arbiter of the public's right to be informed. ${ }^{280}$ Arguably, the Supreme Court's dichotomy between gathering and publication can be interpreted as an attempt to accommodate both theories by applying the principles of each to separate aspects of the news dissemmation process.

But if the entity that controls gathering effectively controls publication, the dichotomy collapses, the accommodation skews in favor of social-responsibility principles, and government obtains a distinct advantage in the contest between government and the press. ${ }^{281}$ By asserting that publication is not at issue, the Court is able to proceed with a mechanistic apphication of a "no greater than" formula ${ }^{282}$ that allows it to avoid deciding whether publication may be prevented, or content

276. In this context objectivity means a bland balance that obscures more than it reveals. See notes $46-47$ supra.

277. See notes 88-90 supra and accompanying text. For example, Newsday's White House correspondent was repeatedly snubbed $\mathrm{m}$ his requests for information and access privileges during the Nixon Administration's tenure after Newsday ran a six-part series and editorial critical of Nixon's closest friend, Bebe Rebozo. D. Wise, supra note 83, at 218-22. Timothy Crouse, referring to this same incident, described the tactic as a "freeze-out." T. CROUSE, THE BoYs ON THE Bus 233-35 (1972).

278. See notes 77-86, 99-107 supra and accompanying text.

279. Social-responsibility theory can easily justify a broad exception to the doctrine against prior restraint that would allow publication to be precluded whenever government conceivably could lave prevented access to information. See notes 282 \& 292 infra. Prior restraint can promote the public interest in a given case, see note 84 supra, and thus is integral to implementation of social-responsibility theory. See notes 193-94, 239-42 supra and accompanying text. Likewise, dictating the content of speech is not alien to a social-responsibility scheme. Sce notes 195-96, 199-200 supro and accompanying text.

280. See notes 121-54 supra and accompanying text.

281. See notes 1-3 supra and accompanying text.

282. The Court's analysis produces the same results as a test proposed by Justice Harlan. Significantly, Harlan was dissenting from the Court's refusal to enjoin a publication when he proposed the two-part test: (1) is the subject matter within the Executive's foreign-relations power to classify, and (2) did the appropriate official classify the material? New York Times Co. v. United States, 403 U.S. 713, 757 (1971) (Harlan, J., dissenting). See also Alfred A. Knopf, Inc. v. Colby, 509 F.2d 1362, 1368 (4th Cir.), cert. denied, 421 U.S. 992 (1975). Deference was due the government-not the press-in determining whether the need was sufficiently great to classify the material. 
dictated, by selective access to information. ${ }^{283}$ In circumventing this difficult question the Court nonetheless answers it.

Deference to government regulation of news gathering may have far-reaching ramifications. ${ }^{284}$ For example, the media are forced to assume the status assigned to them in Richmond Newspapers, Inc. v. Virginia ${ }^{285}$ of "surrogates for the public"286 who plead with government to open its doors and reveal its records. Implicit in the concept of a surro-

Under Harlan's framework, if the authority to classify is not limited to the Executive, see, e.g., Gannett Co. v. DePasquale, 443 U.S. 368 (1979) (denial of access to pretrial judicial proceeding, and implicitly to transcript, upheld); Nixon v. Warner Communications, Inc., 435 U.S. 589 (1978) (congressional restriction of common-law right of public access to Watergate tapes upheld), and if the constitutional authority may be construed in textual references other than the foreignrelations power, e.g., U.S. CoNST. art. I, §8, cls. 3, 18 (commerce and necessary and proper clauses); id. art. III, $\S \S 1-2$ (the judicial power) (by implication); id amend. XIV, $\$ 5$ (enforcement clause), then goverament officials have wholesale power to classify or to deny access. Indeed, this model seems to govern all the results in the news-gathering cases, even Richmond, because the Court can be interpreted as holding that the authority to deny access to trials exists but was abused. The holdings in the news-gathering cases evince the same concern for judicial deference to the discretion of other branches.

Of course, one as sensitive to first amendinent values as Harlan, see G. GUNTHER, CoNSTiTUTIONAL LAW 1252 (9th ed. 1975), might have construed the requisite governmental authority very narrowly. See Oregon v. Mitchell, 400 U.S. 112 (1970) (nullified in part by U.S. CoNST. amend. XXVI):

Although Congress' expression of the view that it does have power to alter state suffrage qualifications [under the fourteenth amendinent] is entitled to the most respectful consideration by the judiciary, coming as it does from a coordinate branch of government, this cannot displace the duty of this Court to inake an independent determination whether Congress has exceeded its powers.

400 U.S. at 204 (Harlan, J., concurring in part and dissenting in part) (footnotes omitted).

Such sensitivity does not overcome the objection that by exercising the power to impede gathering, even when the power is delegated in accordance with a strict interpretation, the government is i fact impeding publication in direct contravention of the first amendrnent. The imposition on publication seems not to have been determinative in Harlan's dissent in New York Times.

283. As Justice Powell has observed, "[This analysis] obviates any need to enter the thicket of a particular factual context in order to determine the effect on First Amendment values of a nondiscriminatory restraimt on press access to information." Saxbe v. Washington Post Co., 417 U.S. 843, 875 (1974) (Powell, J., dissenting).

284. If gathering is recognized as the determinative component of the dissemination process, then government may be able to prevent publication of infornation already in the press's possession if the government had authority to prevent its release initially. See Snepp v. United States, 444 U.S. 507 (1980) (government authority upheld to bind forner employee to contract signed at beginning of employment prohibiting release of any information without prior review by agency); cf. Federated Publications v Swedberg, 633 P.2d 74, 77-78 (1981) (court that has authority to exclude all of public, including press, may allow press attendance on the condition that the press abide by bar-bench-press guidelines).

285. 448 U.S. 555 (1980).

286. 448 U.S. at 573 (Burger, C.J.); see Brief of Appellee at 49-50, 54, 106-07, Chandler v. Florida, 449 U.S. 560 (1981). See generally Houchins v. KQED, Inc., 438 U.S. 1, 32-34 (1978) (Stevens, J., dissenting); Saxbe v. Washington Post Co., 417 U.S. 843, 863-64 (1974) (Powell, J., dissenting). Chief Justice Burger declined to use the proposed role of the press as surrogate as the basis for an affirmative statutory duty to publish certain material. Miami Herald Publishing Co. v. Tomillo, 418 U.S. 241, 251 (1974). 
gate or proxy is that the press not only has a "right" to disseminate the information that government releases, but that it has no right not to disseminate such information. ${ }^{287}$ Should the press refuse to disseminate information that government has determined the public slould know, the press renounces its surrogate function and discredits its claim to the information. Should the press assert a news-gathering right on behalf of the public's right to know it would be accountable to the pubhic-and ultimately to government-in accordance with social-responsibility primciples. ${ }^{288}$

The Court's present analysis of the news-gathering right subverts the foundations of the right to publish. Under this analysis libertarian primciples cannot justify access to information because they apply only to publication and it is fatally inconsistent to invoke social responsibility primciples to obtain information on behalf of the public but then contend that the press's only obligation concerning publication is to its private interests. ${ }^{289}$ The press is confronted with a no-win situation if it must assert a right to gather news to exercise its right to publish; the gathering right should not be analyzed in isolation froin the riglit to publish.

Garrett v. Estelle 290 illustrates the inseparability of gathering and publication and the extent to which the state can substitute its judginent of appropriate content. By framing the issue in terms of news gathering the Court of Appeals for the Fifth Circuit substituted for analysis the conclusion that a television cameraman has no greater right than the public to film an execution. ${ }^{291}$ Although never specifically stated, the Fifth Circuit's rationale appears to be that it could not find a case in which the government had authorized such a right on behalf of the public. This failure to unearth a public right was determinative of the

287. See BeVier, supra note 43 , at 516 \& n.126.

The media have no specific legal obligation to inform. . . . Indeed, a strict libertarian philosophy would claim that the press has no obligation nor responsibility to anyone except itself. But thc social responsibility concept decrees otherwise. If the media are to function freely and be protected by the First Amendment, they must assume full responsibility for what they print and air. And they must be responsible surrogates of the people, purveying information to meet the people's "right to know."

C. SteINBeRG, supra note 275 , at 217.

288. See notes 137-62 supra and accompanying text. Reliance on the largcly undefined contours of the public's right to know is an outright invitation for govcrnmental intervention prior to publication to determine what the public is entitled to know. See Goodalc, supra note 160, at 3234.

289. Among journalists' multitudimous imconsistencies, Professor John Merrill noted their propensity to "speak of the people's right to know as they routinely keep the people from knowing certain things." J. MERRILL, supra note 56, at 17.

290. 556 F.2d 1274 (5th Cir. 1977), cert. denied, 438 U.S. 914 (1978).

291. 556 F.2d at 1278-79. 
cameraman's asserted right. ${ }^{292}$ The court noted that the cameraman was not being prohibited from simulating or relatimg the imcident. 293 He thus could convey the same content as the two print reporters 294 admitted to witness the execution. ${ }^{295}$ In suggesting alternatives to broadcasting the actual execution, however, the court demonstrated the power of the state to control the content of the broadcast by controlling the information gathering. Because a simulation or a narrative was acceptable but a broadcast was not, the content of the latter must vary in a substantive, qualitative way from the content of the former. ${ }^{296}$ As the district court had observed, the Texas prison officials did not object to giving the cameraman plysical access to the execution chamber but to the possible public reaction when the dramatic event was broadcast into living roolns across the country. ${ }^{297}$ The state successfully substi-

292. The court did not find it significant that the prison authorities had already planned to broadcast the event via closed circuit television to a select audience. See id. at 1279. The court sidestepped the ingenious argument of amicus curiae that the closed circuit broadcast constituted a publication. See Amicus Brief for Appellee, Reporters Comm. for Freedon of the Press, The Newspaper Guild, AFL-CIO, and Radio Television News Directors Ass'n at 14, Garrett v. Estelle, 556 F.2d 1274 (5th Cir. 1977). Once broadcast, the state could not restrict further dissemination without overconing the heavy presumption of unconstitutionality imposed on prior restraints. See Southeastern Pronıotions, Ltd. v. Conrad, 420 U.S. 546, 557-58 (1975); Litwack, The Doctrine of Prior Restraint, 12 HARv. C.R.-C.L. L. Rev. 519, 533-34 (1977). But, as is always the case, the court had the last word in this exercise in semantics, declaring that prior restraint was not at issue because the state was affording only access to the broadcast. See 556 F.2d at 1279-80.

293. 556 F.2d at 1279.

294. See id. at 1276-77.

295. The appeals court asserted that alternate neans of reporting the event would not inhibit the free flow of ideas and infornation and that no differences existed in the quality of the various methods of reporting. Id. at 1278. But see Zacchini v. Scripps-Howard Broadcasting Co., 433 U.S. 562, 581 (1977) (Powell, J., dissenting).

296. Although the content of a newspaper is primarily verbal, the essence of the content of the television mediun is pictorial. See Frank, The 'Grammar of Film' in Television News, 51 JourNALISM Q. 245, 245 (1974); Scliunenaan, Visual Aspects of Television News: Communicator, Message, Equipment, 43 JoURNALISM Q. 281, 282-83 (1966); Zimmerman, supra note 89, at 66065,668 ("The various communications media . . . do not produce speech that is interchangeable."); Media and the First Amendment in a Free Society, 60 GEO. L.J. 867, 937 (1972).

[I]t is the camerawork, motion picture film, and edited newsfilm which give television this characeristic of personalized nuass communication. In the ininds of many, the sinew and strength of electronic reporting is newsfllm.

A story is a story. But with newsfilm, the sane story is an experiencc; a hiving animated event the viewer shares with the newsfilm reporter. Newsfilm nuakes your viewer an eyewitness to the news. It is a fresh, provocative, challenging approach to journalisn, bursting with impact and realism.

J. AtKins \& L. Willette, Filming TV News and Documentaries 10 (1965).

Control of the technological aspects of news gathering is the most effective means of controlhing broadcasting. See Allen v. Conbined Communications Corp., 7 Media L. Rep. (BNA) 2417, 2419 (D. Colo. July 22, 1981).

297. See Garrett v. Estelle, 424 F. Supp. $468,472-73$ \& n.2 (N.D. Tex.), rev'd, 556 F.2d 1274 (5th Cir. 1977), cert. denied, 438 U.S. 914 (1978). See generally 424 F. Supp. at 469-70 (media policy regarding executions promulgated by Texas Department of Corrections). 
tuted its judgment concerning the legitimate public interest in the broadcast for that of the broadcaster. The scope of the broadcasting right was necessarily delimited by the scope of the gathering right. Even if the cameraman had chosen to combine the gathering and broadcasting into a single act by broadcasting the event live, the state's ability to control the gathering component inost likely would have taken precedence over the cameraman's supposed ability to control the broadcast.

Even if the broadcast of an actual execution comprises primarily emotive rather than informational content, restriction of such expression creates serious constitutional questions;"298 the "ernotive function .. . may often be the more important element of the overall inessage sought to be communicated."299 The state clearly departs from a libertarian scheme when it imposes conditions on gatlering for no other reason than to suppress soine expression while allowing dissemmation of other, related expression. Government breaches the rule of neutrality, ${ }^{300}$ a rule that social-responsibility theory does not require.

\section{A News-Gathering Right Reconsidered.}

The application of social-responsibility principles to press rights of gathering/publication stems from a fundamental analytical error made $\mathrm{m}$ the first prison-access cases. When the maxim that the press is due rights no greater than those of the public was borrowed from Branzburg to justify the results of Saxbe and Pell, ${ }^{301}$ the analysis was restricted to the narrow question of whether the press inerited a privilege not enjoyed by the public. ${ }^{302}$ The Court inay be understood as beimg guided by the libertarian doctrime that governmental conferral of access privileges may compromise the independence of those privi-

298. See Cohen v. California, 403 U.S. 15, 26 (1971); Collin v. Smith, 578 F.2d 1197, 1200-02 (7th Cir.), cert. denied, 439 U.S. 916 (1978); Village of Skokie v. National Socialist Party, 69 III. 2d 605, 611-12, 373 N.E.2d 21, 22-23 (1978) (per curiam); Rockwell v. Morris, 12 App. Div. 2d 272, 282, 211 N.Y.S.2d 25, 35, affd mem., 10 N.Y.2d 721, 722, 219 N.Y.S.2d 268, 269, cert. denied, 368 U.S. 913 (1961) ("shocking quality" and "alarming impact"). Professor Daniel Farber, in an engaging and insightful analysis of Justice Harlan's first antendment philosophy, concluded that offensive expression has merit if for no other reason than because it reinforces people's understanding of the reason for its offensiveness. See Farber, Civilizing Public Discourse: An Essay on Professor Bickel, Justice Harlan, and the Enduring Significance of Cohen v. California, 1980 DuKE L.J. 283, 301-03. See note 23 supra and accompanying text.

299. Cohen v. California, 403 U.S. 15, 26 (1971).

300. See Bezanson, supra note 1, at 763-65. See notes 21-32 supra and accompanying text.

301. See Saxbe v. Washington Post Co., 417 U.S. 843, 850 (1974); Pell v. Procunier, 417 U.S. 817, 834-35 (1974).

302. See Saxbe v. Washington Post Co., 417 U.S. 843, 849-50 (1974); Pell v. Procunier, 417 U.S. 817, 833-34 (1974). 
leged. ${ }^{303}$ The press in Saxbe and Pell argued, however, that a substantial number of persons already enjoyed access to interview specific inmates. ${ }^{304}$ Therefore, the issue was not one of special access, but of equal access. More significantly, the Court's analysis obscured basic issues of the government's authority to prohibit access altogether or to provide access at its discretion, as well as the issue of the interrelationship between gathering and publication or broadcasting. By not addressing these issues, the Court resolved them in the government's favor.

A straightforward libertarian analysis may dictate that anything that can be published can be gathered. The private interest in disseminating particular content seems no different at the gathering than at the publication stage, and governmental interference at any stage seems to contravene the libertarian principle of independence from government. If anything could be gathered absent a clear and present danger, however, the likelihood is that the clear and present danger test would be diluted rather than the gathering right expanded.305 Thus, constructing a gathering right defined in terins of the publication right may create irresistible pressures to narrow the publication right. The extent of protection may be imversely proportional to the generosity with which a prior restraint is defined. 306 An alternative to conjuring up a gathering right of dimensions lesser than or equivalent to those of the publication right is to assess forthrightly the scope of government authority to conceal its processes from scrutiny. This analysis can be facilitated by inaintaining the first ainendment focus solely on the publication or speech component of the dissemination process, and by examining in

303. See Bezanson, supra note 1 , at 734.

304. Relatives, friends, lawyers, clergymen, and public officials could visit with prisoners at length. See Comment, The Right of the Press to Gather Information After Branzburg and Pell, 124 U. PA. L. Rev. 166, 188 n.124 (1975) (quoting Brief for Appellant at 6, Pell v. Procunier, 417 U.S. 817 (1974); Brief for Respondents at 43-44, Saxbe v. Washington Post Co., 417 U.S. 843 (1974)).

305. See D. Gillmor \& J. Barron, Mass Communication Law 440 (3d ed. 1979); Sanford, Richınond Newspapers: End of a Zigzag Trail?, Colum. Journalism Rev., Sept.-Oct. 1980, at 47. Access to grand jury proceedings, tax records, and discussions of prison security are just a few examples of the many hard questions that might arise. See also Statler, Let the Sunshine In?, 67 A.B.A.J. 573, 574-75 (1981) (commitment to openness adversely affected effectiveness of Consumer Product Safety Commission).

306. See D. GIllmor \& J. Barron, Mass Communication Law 17 (3d ed. 1979); Dworlin, supra note 43 , at 50 (if the first amendment becones an "all-purpose shield," then it will ultimately be weakened). James Madison, who presented the first draft of the first amendment, cautioned against absolute provisions in the Bill of Rights because the provisions "lowever strongly marked on paper will never be regarded when opposed to the decided sense of the public, and after repeated violations in extraordinary cases they will lose even their ordinary efficacy." Letter to Thomas Jefferson (Oct. 17, 1788), reprinted in 5 The WrITINGS OF JAMES MADISON 274 (G. Hnnt ed. 1904). 
detail an aspect of that process that has been largely ignored-government speech.

Government, too, has a right of speech. ${ }^{307}$ The speech-and-debate clause $^{308}$ of the United States Constitution is one source of government's speech right. Alexander Meiklejohn contends that the speechand-debate clause was intended to protect absolute freedom of discussion of public affairs. ${ }^{309}$ But because Meiklejohn saw no distinction between the governors and the governed, ${ }^{310}$ the protection of the clause was merely derivative of the first amendment freedoin enjoyed by all. ${ }^{311}$ Meiklejohn's interpretation of that freedom is consistent with social-responsibility principles in ensuring the right, not of the speaker, but of the audience. ${ }^{312}$ Thus, speech by governors is not "protected" for the benefit of government, but for the benefit of the general welfare. Meiklejohn posited that the protection of expression is premised on its value of pronroting self-government. ${ }^{313}$ It seems that anything government says is by its nature related to self-government. ${ }^{314}$ But it is that which government prefers not to say that is of greatest relevance: Just so far as, at any point, the citizens who are to decide an issue are denied acquaintance with information or opinion or doubt or disbelief or criticism which is relevant to that issue, just so far the result nuust be ill-considered, ill-balanced planning for the general good. It is that mutilation of the thinking process of the community against which the First Amendment to the Constitution is directed. The principle of the freedoin of speech springs froin the necessities of the program of self-government. ${ }^{315}$

307. See Methodist Fed'n for Social Action v. Eastland, 141 F. Supp. 729, 731 (D.D.C. 1956) (court cannot order Congress not to publish a potentially defamatory telegram); People ex rel. Difanis v. Barr, 83 Ill. 2d 191, 209, 414 N.E.2d 731, 738-39 (1980) (federal and state rights of government expression may be limited by Open Meeting Act); Z. CHAFEE, JR., supra note 90, at 723-82; COMMISSION, supra note 109, at 81; T. EMERSON, supra note 19, at 697-716; L. TRIBE, AMERICAN CoNSTITUTIONAL LAW 590-91 (1978); Yudof, When Governments Speak: Toward a Theory of Government Expression and the First Amendment, 57 TEx. L. REv. 863, 865 (1979); Ziegler, supra note 275, at 580-81; cf. Barnstone v. University of Houston, 514 F. Supp. 670, 683 (S.D. Tex. 1980) (public television station a governmental entity for purposes of first amendment analysis), rev'd on other grounds, 660 F.2d 137 (5th Cir.), reh'g en banc granted, 662 F.2d 1110 (1981).

308. U.S. CONST. art. I, $\S 6$.

309. A. MEIKLEJOHN, supra note 144, at 35-37; see Barr v. Mateo, 360 U.S. 564, 569 (1959) (Harlan, J.).

310. A. MEIKLEJOHN, supra note 144, at 6.

311. Id. 37.

312. See notes 168-69 supra and accompanying text.

313. See A. Menkiejohn, supra note 144, at 24-27. Compare id. at 35-37 with id. at 37-39.

314. One may note, by analogy, the broad scope of "legislative acts" protected by the speechand-debate clause. See Gravel v. United States, 408 U.S. 606, 616-18, 624 (1972). But see Hutchinson v. Proxmire, 443 U.S. 111, 127-33 (1979).

315. A. MeIKLEJoHN, supra note 144, at 26 (emphasis deleted). 
Application of social-responsibility principles to government expression imposes affirmative obligations on government to provide the public with information. ${ }^{316}$ The ramifications of this statement become more apparent when it is recognized that it is governmental ${ }^{317}$ expression that proponents of a news-gathering right most often seek to gather. ${ }^{318}$ Because the facts that the public is entitled to know are in

316. See Emerson, supra note 160, at 14. Professor Yudof notes that although the right to know may be a sound basis for compelling disclosure of information that government prefers not to reveal, it does not support an independent right of government expression. "The right to know formulation simply obfuscates the analysis of how and why governments shonld have rights against the community under a first amendment adopted to limit government power." Yudof, supra note 307 , at 869 . A social-responsibility proponent may respond that no "rights against the community" are contemplated when it is the right of the community that serves as the touchstone. Yudof is concerned, however, with the excesses of government speech; the present analysis focuses more on the deficiencies in government speech and press. Yudof's articulation of an ultra vires standard to govern government participation in communications networks, see id. 912-17, demonstrates his concern with "ways to limit government speech." Id. 918. The present analysis is concerned with encouraging government speech, especially in those cases in which government would rather withhold in whole or in part information relevant to self-governance. The two analyses can be considered harmomous if one views the present analysis as concentrating on the first half of the following sentence, and Yudofs on the second half: "Government expression is critical to the operation of a democratic polity, but the power of governments to communicate is also the power to destroy the underpinnings of government by consent." Id. 865. Yudof's orientation is analogous to the proposition advanced by Professor Van Alstyne that the first amendment "implicitly requires some silencing of the government itself" Van Alstyne, supra note 271, at 532. See generally Ziegler, supra note 275.

317. Because application of social-responsibility theory hinges under the proposed analysis on a determination that the source of speech is government, government speech must be clearly distinguished from nongovernment speech. Government is not, of course, a monolith; its voices emanate from numerous individuals. One method of determining whether those individuals are engaged in expression is to resort to "state action" analysis. See, e.g., CBS v. Democratic Nat"1 Comm., 412 U.S. 94, 114-21 (1973) (Burger, C.J.). But the ambiguities in such analysis, compare id. with id. at 174-81 (Brennan, J., dissenting), do not lend themselves to the clarity with which the private and public spleres should be distinguished. See Jaffe, The Editorial Responsibllity of the Broadcaster: Reflections on Faimess and Access, 85 HARv. L. REv. 768, 783 (1972). A more definitive basis is therefore desirable. Because it inay be prudent to err in favor of private interests, the duties associated with government speech may be limited to those in government's employ. The speech of government employees could then be broken down further into speech related to government and speech not related to government. See T. EMERSON, supra note 19, at 563-92. The possibility that this categorization may still prove overimclusive should be considered in light of the possible underinclusiveness of an even narrower categorization, such as speech by public officials. See Hutchinson v. Proxmire, 443 U.S. 111, 119 n.8 (1979) (the category of "public official" does not include all public employees, although its contours are not yet precisely drawn).

318. See Yudof, supra note 307 at $872-74$. "Concerns about govepnment expression crucially influence first amendment cases concerning . . . the right of the press to gather information for publication, and the rights of imdividuals and organizations to compel government disclosure of information." Id. 873.

Just as the speech-and-debate clause protects both written and oral communications, see Doe v. McMillan, 412 U.S. 306, 312-13 (1973); Gravel v. United States, 408 U.S. 606, 617 (1972), the first amendment as apphed to government speech or expression as the terms are used here encompasses all forms of verbal communication. Thus, the information most commonly sought by the press clearly involves government expression, whether it involves government documents or the 
the government's possession, the government appears to be the appropriate party to assume the obligations incumbent on the speaker in a social-responsibility scheme. It seems paradoxical that under the current approach the press inust assert the public's right to know to exercise its right of expression, but the government need cite only its own interests as justification for speaking or not speaking.

Unlike Meiklejohn's analysis, however, the present analysis contemplates application of libertarian, not social-responsibility, principles to the speech rights of the governed. If government abides by its obligation under social-responsibility theory to inforn the public then it in large part compensates for any possible shortcomings of libertarian ideals, ${ }^{319}$ though leaving individuals and the press free to pursue their re-

content of government proceedings such as meetings, trials, and hearings. The prison-access cases are somewhat of an anomaly because the expression element is not as clearly identifiable. Access to a certain area of a jail or prison seems to involve information in a visual form, rather than in an oral or textual form. Government conduct in managing a prison constitutes government speech only if one resorts to a conduct-as-speech analysis. If this proposition is accepted, then regulation of the expressive element of reception by an audience, see note 156 supra and accompanying text, has to further an important or substantial governmental interest, be unrelated to the suppression of expression, and be no greater than is essential to the furtherance of the governmental interest. See United States v. O'Brien, 391 U.S. 367, 377 (1968).

The second requirement has been characterized as the Court's "definitive statement" of its test. Ely, Flag Desecration: $A$ Case Study in the Roles of Categorization and Balancing in First Amendment Analysis, 88 HARv. L. REv. 1482, 1496 (1975). But see Farber, supra note 298, at 743$47 \& \mathrm{nn} .90,93-94 \& 96$. This requirement perhaps would be the element inost easily satisfied because regulation of the conduct would be intended to restrict the expression of the media, see notes 265-70 supra and accompanying text. Of course, as ordinarily interpreted, the regulation must be directed at the conduct of the party whose expression is sought to be suppressed, see United States v. O'Brien, 391 U.S. 367 (1968) (regulation of draft card burning constitutional infringement of burner's expression), rather than at the expression of third parties such as the press in the prison-access cases. To contend that the government regulates its own conduct to suppress its own expression is result-oriented, however, because the conduct was construed as expression initially.

Another possibility is to leave the conduct-expression debate to others, compare Tinker v. Des Moimes Indep. Community School Dist., 393 U.S. 503, 515 (1969) (Black, J., dissenting) and T. EMERSON, supra note 19, at 8-9, 19, 328-44 with L. TRIBE, AMERICAN ConstituTIONAL LAw 598601 (1978) and Baker, Scope of the First Amendment Freedom of Speech, 25 U.C.L.A. L. REv. 964, 1009-12 (1978), and explore the potential of the social-responsibility theory. Because the public should know more about prisons, see Houchins v. KQED, Inc., 438 U.S. 1, 36-38 (1978) (Stevens, J., dissenting); Burger, Our Options Are Limited, 18 VILL. L. REv. 165, 167 (1972), it seems incumbent on the government to provide this information, at least in part, by disseminating the information and ensuring that both the media and the general public have access to it. Furthermore, social-responsibility principles have been invoked to require that information be substantiated. See note 198 supra and accompanying text. Government pronouncements on prison conditions and occurrences, which the government would be obligated to provide, can best be substantiated by giving access to press and public alike and by allowing the media to employ the tools peculiar to their medium to fulfill their constitutionally protected function. See Houchins v. KQED, Inc., 438 U.S. 1, 17-18 (1978) (Stewart, J., concurring).

319. See notes 116-20, 124-26 supra and accompanying text. 
spective private interests. 320 If government cannot make itself responsible to the public, there exists no basis for believing that it can make the press or any other institution responsible.

Under this interpretation of the Constitution, all branches of government at all levels assume the social responsibilities of government. Each government entity has an obligation to further the right of the public to be informed of the functioning of that entity. Ideally, every discrete government entity would estabhish policies or enact laws providing for nnaximum access to records and proceedings. State legislatures, ${ }^{321}$ as well as Congress, ${ }^{322}$ have already assumed this responsibility to varying degrees. Ironically, on occasion courts have read negative inferences into disclosure provisions, ${ }^{323}$ thereby whittling away the provisions' scope and freeing government fron1 its responsibilities. The public information provision of the Administrative Procedure Act, for exainple, lias come to be considered "inore as a withholding statute than a disclosure statute." ${ }^{\text {324 }}$

Public officials, at times, have dehiberately attempted to shirk their responsibilities by circumventing application of open-1neetings or open-records statutes; ${ }^{325}$ and good-faith disputes inevitably will arise

320. See Yudof, supra note 307, at 863 . "[C]ourts could consider the need to strengthen centers of communication that will counter or check the persuasive powers of governments." Id. 872. "The greatest threat to the system of freedom of expression emanates from the welfare state, not from a multitude of corporate, mass media, union, and other voices . . . . [T] he potential for pluralism lies in strengthening all elements of private sector communication." Id. 873 (emphasis in original); see T. EMERSON, supra note 19, at 671 (approves government action to extent that it encourages inultiplicity of private outlets).

321. Alabama enacted the first open-meetings statute in 1915. See Comment, Where's the Sunshine? Inadequacy of Pennsylvania's Open Meeting Law, 82 Dick. L. REv. 719, 720 n.4 (1978). For a complete listing of the laws effective in each of the other 49 states and the District of Columbia, see id 719 n.4. For a compilation of the public-records laws effective in 47 states, see Comment, The Pennsylvania Right to Know Statute: A Creature of the Legislature Shaped by the Judiciary, 82 Dick. L. REv. 749, 749 n.4 (1978).

322. See 5 U.S.C. $\$ \$ 552,552(b)$ (1976).

323. See Cox v. Department of Justice, 576 F.2d 1302, 1307-08 (8th Cir. 1978); Hawkes v. IRS, 467 F.2d 787, 795 (6th Cir. 1972), on remand, No. C-70-409 (W.D. Teun. Nov. 5, 1973), affd, 507 F.2d 481 (6th Cir. 1974); United States v. Imbrunone, 379 F. Supp. 256, 260-61 (E.D. Mich. 1974). But see Jordan v. Department of Justice, 591 F.2d 753, 761 (D.C. Cir. 1978) (en banc); Caplan v. Bureau of Alcohol, Tobacco \& Firearms, 445 F. Supp. 699, 705 (S.D.N.Y.), aff'd on other grounds, 587 F.2d 544 (2d Cir. 1978). See also Pember, supra note 9, at 1190, 1198 (in enactment of publicrecords laws, right of privacy crcated where none had been before).

324. EPÄ v. Mink, 410 U.S. 73, 79 (1973) (construing Administrative Procedure Act, cl. 324, $\S 3,60$ Stat. 238 (1946) (codified at 5 U.S.C. $\$ 552$ (1976)). See also Note, supra note 270, at 22325.

325. See, e.g., Kissinger v. Reporters Comm. for Freedom of the Press, 445 U.S. 136, 154-55 (1980) (documents deeded to Library of Congress); Sacramento Newspaper Guild v. Sacramento County Bd., 263 Cal. App. 2d 41, 49-50, 69 Cal. Rptr. 480, 486-87 (1968) (citing report denouncing widespread evasion of open-meeting obligations through "sneak" neetings and by means of euphemisms such as executive session, conference, caucus, study or work session, and meeting of the 
over the scope and practical implementation of the public's right to know. ${ }^{326}$ Although the constitutional mandate to forward the public interest im possessing information cncompasses all branches, the judiciary, in addition to revealing its own processes, is required to resolve disputes concerning other branches. 327

Whether courts consider the obligations of government to inform the public or the scope of a news-gathering right, the "public's right to know" yields no definitive standards to guide decisionmaking. Posing the question in terms of government expression more clearly focuses the analysis im two respects. First, no longer must the courts engage in futile attempts to segregate the gathering component of the communication process. The issue is starkly presented as the obligation of governinent to inform the public. Extraneous issues, such as the institutional status ${ }^{328}$ of the press as an intermediary, no longer detract from that central question. Second, when the question is posed in terms of government expression it is clear that the courts are not substituting their judgment for that of the media, but for that of a coordinate

committee of the whole); People ex rel. Difanis v. Barr, 83 Ill. 2d 191, 201, 414 N.E.2d 731, 735 (1980) (convening informal caucus to discuss public business constitutes illegal circumvention of Open Meetings Act); D. GILLMOR \& J. BarRon, Mass Communication LaW 469 (3d ed. 1979) ("open" meeting lield in neighboring state). Such instances indicate a tendency toward secrecy in government. See Ray v. Turner, 587 F.2d 1187, 1209 (D.C. Cir. 1978) (quoting Sen. Baker); J. MERRILL, supra note 56, at 105; J. WIGGINS, FREEDOM OR SECRECY at X (rev. ed. 1964); Brant, The Constitution and the Right to Know, in MASS MEDIA AND THE LAw 73 (D. Clark \& E. Hutchison eds. 1970); Knoll, If. . ., THE QUiLL, June 1979, at 31 (published news stories classified as secret); Morland, The H-bomb Secret, The Progressive, Nov. 1979, at 14, 15 (Scnator's questions regarding a plutonium shortage classified as secret); Pember, supra note 9, at 1189; Note, supra note 270 , at 210 .

One author interpreted recent judicial and legislative developments concerning the federal Freedom of Information Act to indicate "a clear trend toward restricting the availability of disclosure." Comment, Developments Under the Freedom of Information Act-1980, 1981 DuKE L.J. $338,376$.

326. See note 288 supra and accompanying text. Professor Be Vier, who finds no support in the Constitution for a right to know, suggests that everything, or at least most things, that the public needs to know are revealed in the give-and-take of the political process. Be Vier, supra note 43 , at $512-15$. The question indeed inay fairly be raised whether the public has a need or even a desire to be fully informed. See Blasi, supra note 20, at 561-62.

In fact, some have posited a point at which there may be too much information. See Metromedia, Inc. v. City of San Diego, 101 S. Ct. 2882, 2916 (1981) (Stevens, J., dissenting); W. HockING, supra note 23 , at 164 n.4.

In the interest of realism it is pertinent to remark at this point that there is such a thing as a too expressive, too loquacious, too unreticent society, taking out in endless talk what a soberer guard at the lips would reduce to relevant and sincere discourse. The liberal tradition has taken a too quantitative view of the virtues of speecl; and the time is not far away when lumanity will revolt aganist the flood of blab and print. Id. 89 n.3.

327. See D. Gillmor \& J. Barron, Mass Communication law 439, Comment 2 (3d ed. 1979).

328. See note 1 supra and notes 234-39 supra and accompanying text. 
branch of government. The Supreme Court has alluded to the dehcate separation-of-powers problems that such inquiry entails, ${ }^{329}$ but it has avoided them by framing the issue as one of news gathering and by resorting to the "no greater than" formula, thereby imphicitly deferring to the other branches. 330

Because the basis for judicial review rests on the twin postulates that the Constitution is not only law, but law that the courts can "expound and interpret,"331 it is imperative that the courts have a definitive constitutional criterion to determine the obligations of other branches. ${ }^{332}$ The criterion on which the courts must expound is the value of self-government inherent in the first amendment, and indeed throughout the Constitution. ${ }^{333}$ Indisputably aware of government's obligation to account to the public, the framers enumerated various specific affirmative duties to commumicate. ${ }^{334}$ But the affirmative duty of the greatest scope is necessarily the least specific. The free flow of information among citizens and between citizens and their government is all that keeps the government "in due subjection"335 to its citizens rather than vice versa. 336 The power of information is the power by which the public controls government. ${ }^{337}$ But the power of information is a two-edged sword, and government can use it to its own advan-

329. See Houchins v. KQED, Inc., 438 U.S. 1, 12 (1978) (Burger, C.J.). See notes 240-43 supra and accompanying text.

330. See notes 236-37, 282-83, 292 supra and accompanying text.

331. Marbury v. Madison, 5 U.S. (1 Cranch) 137, 177-78 (1803); see L. Tribe, AMERICAN Constitutional Law 24 (1978).

332. Judges should have a more specific justification for their decision than the palatability of the result, see Cass, supra note 20, at 1309, particularly when substituting their judgment for that of another branch of government.

Professor Alexander Bickel noted that the judiciary is particularly well-suited to the contemplation and pursuit of principles. See A. Bicker, THE LeAST DANGerous BrANCH 25-28 (1962). See generally Freund, The Judicial Process in Civil Liberties Cases, in Civil Liberties AND Civi RiaHrs 3, 4 (V. Stone ed. 1977) (courts set a tone by articulating philosophical and legal bases for our community). If the principle of accountability to the public is indeed a cornerstone of a democracy, then its desuetude would most properly and effectively be exposed in a Supreme Court opinion. The Court itself provides a salutary example of accountability by revealing in detail, at least ostensibly, the rationales for its decisions, thus subjecting its opinions to scrutiny and criticism. See Lewis, supra note 29, at 803 . No less should be expected from it, however. See C. STEINBERG, supra note 275, at 126-29, 131-32.

333. A. MEIKLEJOHN, supra note 144, at 14-15.

334. See U.S. ConsT. art. I, § 5, cl. 3; id. art. I, § 9; id. art. II, § 3.

335. Grosjean v. American Press Co., 297 U.S. 233, 247 (1936).

336. "The informing function of Congress should be preferred even to its legislative function. . . [T]he only really self-governing people is that people which discusses and interrogates its administration." W. WIISON, CONGRESSIONAL GOVERNMENT-A STUDY IN AMERICAN POLITICs 198 (Meridian ed. 1960).

337. Lewis, supra note 29 , at 805-06. 
tage.338 The first amendment stands, however, for a very simple proposition: freedom of speech and press. Once it is realized that that freedom accrues to the public and not to the government, it is evident that the first amendment prohibits government from using the information im its possession in any manner that infrimges the preeminent freedom of the pubhic. The failure to release, in whole or in part, information that furthers self-govcrnment is therefore contrary to the broad command of the first amendment.

Because one cannot assert effectively a right to know something until he knows what he seeks, ${ }^{339}$ a presumption of openness is necessary ${ }^{340}$ to facilitate implemcntation of the first amendment's inandatc. In addition, the ad hoc nature of judicial review ${ }^{341}$ in a social-responsibility scheme $e^{342}$ means that the value of self-goverment provides only a starting point. The presumption in favor of disclosure is necessary to prescribe the initial structuring of the analysis. The presumption may be dispositive if the need for secrecy cannot survive close scrutiny at the outset. $^{343}$ But the government may prcsent compelling reasons for se-

338. See notes 270-77 supra and accompanying text. See W. HockING, supra note 23, at 104; Yudof, supra note 307 , at 865.

339. See Note, supra note 270 , at 215-16. Hocking made this point in the context of the reader's relationship to the press: "He can hardly know, without seeing it, what it is that he misses." W. HockING, supra note 23, at 198.

340. See Yudof, supra note 307, at 873. A presumption of openness replaces any contrary presumption that government agents acted properly in restricting access. See Alfred A. Knopf, Inc. v. Colby, 509 F.2d 1362, 1368 (4th Cir.), cert. denied, 421 U.S. 992 (1975).

341. Commentary on the merits of ad hoc balancing differs. Compare Barenblatt v. United States, 360 U.S. 109, 138, 141-45 (1959) (Black, J., dissenting); Emerson, supra note 67, at 912-14, and Frantz, The First Amendment in the Balance, 71 YALE L.J. 1424 (1962) with Konigsberg v. State Bar, 366 U.S. 36, 49-51 (1961); Dennis v. United States, 341 U.S. 494, 520-25, 542-44 (1941) (Frankfurter, J., concurring); Z. CHAFEE, JR., supra note 28, at 31, and Mendelson, On the Meaning of the First Amendment: Absolutes in the Balance, 50 CALIF. L. REv. 821, 825-26 (1962). See generally Schmidt, Nebraska Press Association: An Expansion of Freedom and Contraction of Theory, 29 STAN. L. REv. 431, 463-64 (1977). Chafee's misgivings about the balancing process are related in Angell, Zechariah Chafee, Jr.-Individual Freedoms, 70 HARv. L. REv. 1341, 1343 (1957), noted in Meiklejohn, The First Amendment is an Absolute, 1961 SUP. CT. REv. 245, 253 n.26.

342. See text accompanying note 9 supra. It can be argued that judicial inquiry into the nature and merit of private interests is discouraged in a hibertarian scheme and that the individualistic value of self-fulfillment is not subject to judicial assessnent. Thus, bibertarian interpretation inay lend itself to per se rules of general applicability. Inquiry into the public interest, on the other hand, seems to require a case-by-case analysis to determine if a public interest indeed exists; such an interest inay even exist on both sides of the judicial scale, in which case judges have to assess on which side the greater public interest rests.

343. "[W] hen government declines to reveal information vital to the formation of intelligent political judgments by citizens, a constitutional or statutory right to know may be decisive in the absence of compelling reasons to withhold the information." Yudof, supra note 307, at 869. 
crecy, ${ }^{344}$ in which case the court must assess the weight of the countervailing right of the public to the information and attempt to balance the opposing interests. ${ }^{345}$ Because the amorphous nature of the public's riglit to $\mathrm{know}^{346}$ subverts principled attempts at balancing, the analysis must necessarily focus on the validity of the government's interests im secrecy. The weight of the government's burden of overcoming the presumption is, of course, crucial.

Foremost, the government's self-imterest in nondisclosure must be identified. Prevention of embarrassment, ${ }^{347}$ unsubstantiated ąssertions of the need for national security, ${ }^{348}$ and other patently self-interested motives are particularly suspect. Although government self-imterest and the public interest are not always mutually exclusive, care must be taken that the meluctable pressures for secrecy do not transform the presumption of openness imto the exception. In those instances in which access wholly frustrates the objectives of government, ${ }^{349}$ or imposes a truly onerous burden on government, or im situations im which not all who seek access can be accominodated, the court should try to compromise rather than merely defer to government's discretion. ${ }^{350}$ Because government is charged with the duty correlative to the public's right to know, efforts to assert the public's right not to know merit particular scrutiny. Most often tlie public alone should decide what infor-

344. See United States v. Nixon, 418 U.S. 683, 705 (1974); Clark v. United States, 289 U.S. 1, 13 (1932); Lewis, supra note 29, at 803; Powell, What Really Goes on at the Supreme Court, 66 A.B.A.J. 721 (1980). Openness may pose obstacles to the accomplishment of an agency's function, see Statler, supra note 305, at 574-75, bnt efficiency and the goals of self-government are not necessarily harmonious, and the former often must give way to the latter. Although autocracy is the most efficient form of government it may not be the best or nuost desirable form of government.

345. See Long v. IRS, 349 F. Supp. 871, 875 (W.D. Wash. 1972).

346. See note 288 supra.

347. See note 83 supra.

348. See New York Times Co. v. United States, 403 U.S. 713, 719 (1971) (Black, J., concurring); United States v. Robel, 389 U.S. 258, 264 (1967); Note, supra note 270, at 229.

349. See note 344 supra.

350. See, e.g., Rose v. Department of Air Force, 495 F.2d 261, 269 (2d Cir. 1974), affd, 425 U.S. 352 (1976); Reston, How Powerful is the 'Monster' Freedom of Information Act?, Des Moines Register, April 29, 1981, at 11A, col. 2. But see Memorandum from Attorney General William French Smith to Heads of all Federal Departments and Agencies on Freedom of Infonnation Act (May 4, 1981) and acconpanying news release (rescission of policy requiring release of records unless demonstrable harm shown). See generally "Washington Counsel," CASE \& CoMmENT, July-Aug. 1981, at 16. Thus, the result in United States v. Richardson, 418 U.S. 166 (1974) (citizen without standing to demand information about CIA budget despite constitutional provision requiring "a regular statenuent and account of the receipts and expenditures of all public money"), is flawed because sone accounting should have been provided even if not a detailed line-by-hine statement. Moreover, the Court einployed a procedural device to obstruct a citizen's attenupts to hold his government accountable when the Court should have been seeking nueans to accommodate the citizen. 
mation it should receive. ${ }^{351}$ Administrative convenience may be considered, but the business of governing should make generous allowances for fulfilling the needs of the governed. ${ }^{352}$

If the government's interest in secrecy proves to be compelling, and if no compromise can be struck to accommodate both interests, then the presumption favoring disclosure inust yield to what is necessarily an ad hoc balancing of interests. Although careful adherence to the presumption should make disclosure the norn and deviation the exception, ${ }^{353}$ this presumption should not have the same force and effect as the "heavy presumption" against prior restraint"354 of nongovernment speech. This dichotony in analysis of presumptions is necessary because different theories govern expression depending on the source of the expression. It is because analysis of governinent expression, which is subject to different limitations and obligations regarding its dissemination, is beginning to control analysis of nongovernment expression through means of the news-gathering artifice that the libertarian foundations of nongoverninent speech are imperiled. A clear distinction must be mamtamed, therefore, between government and nongoverninent speech $^{355}$ and between the theories relevant to each. But of the innumerable puzzling questions that have yet to be answered in applying both theories, determining which theory is apposite seems a minor one. As Professor Ronald Cass observed in another context, "In sum, although the various free speech principles provide neutral, general bases for judicial scrutiny of governinental control ...., they depend ultimately on reasonable judges acting reasonably to resolve specific problems in this area." 356

351. See, e.g., Lamont v. Postmaster Gen., 381 U.S. 301 (1965) (post office detention of "communist political propaganda" unconstitutional). See note 357 infra and accompanying text.

352. Access should not only be allowed but encouraged, for example, by keeping charges as minimal as possible and even waiving them if possible to accommodate the public interest. See, e.g., Freedom of Information Act, 5 U.S.C. \$ 552(a)(4)(A) (1976); Bonine, Public-Interest Fee Waivers Under the Freedom of Information Act, 1981 DukE L.J. 213, 262.

353. Cf. Department of Air Force v. Rose, 425 U.S. 352, 361 (1976) (construing federal Freedom of Information Act); Vaughn v. Rosen, 523 F.2d 1136, 1142 (D.C. Cir. 1975) (construing federal Freedom of Information Act).

354. Nebraska Press Ass'n v. Stuart, 427 U.S. 539, 558 (1976) (quoting Organization for a Better Austin v. Keefe, 402 U.S. 415, 419 (1971)); Southeastern Promotions, Ltd. v. Conrad, 420 U.S. 546, 558 (1975); New York Times Co. v. United States, 403 U.S. 713, 714 (1971) (per curiam); Bantam Books, Inc. v. Sullivan, 372 U.S. 58, 70 (1963).

355. See note 317 supra.

356. Cass, supra note 20, at 1316 . As Justice Frankfurter noted, "[T]he mere formulation of a relevant constitutional principle is the beginning of the solution of a problem, not its answer." Illinois ex rel. McCollum v. Board of Educ., 333 U.S. 203, 212 (1948). 


\section{CoNClusion}

An accessible and accountable government is vitally important to a self-governed society, as is a free and unfettered press. The first amendment ensures both, albeit in different fashions. The determinative consideration in analyzing press atteinpts to hold the government accountable for its actions should not be whether the press seeks to gather or to publish information. If it were necessary to memorialize the affirmative duty of government to communicate to its citizens by opening its doors and revealing its records, there is no better candidate than these sage sentiments of Justice Blackmun:

$[O] n$ close inspection it is seen that the State's protectiveness of its citizens rests in large measure on the advantages of their being kept in ignorance. ...

There is, of course, an alternative to this highly paternalistic approach. That alternative is to assume that this information is not $\mathrm{m}$ itself harmful, that people will perceive their own best interests if only they are well enough informed, and that the best means to that end is to open the channels of commumication rather than to close them. . . . It is precisely this kind of choice, between the dangers of suppressimg information, and the dangers of its misuse if it is freely available, that the First Amendment makes for us. ${ }^{357}$

If, on the other hand, government contimues to exercise unbridled discretion in controlling information, then it will gain the definitive advantage in its adversarial contest with the press.

357. Virginia State Bd. of Pharmacy v. Virginia Citizens Consumers Council, Inc., 425 U.S. 748, 769-70 (1976). 